\title{
Characterization and antimicrobial efficacy of active biocomposite containing polylactic acid, oregano essential oil and nisin for pork storage
}

\author{
Karen Sofía MUÑOZ PABON ${ }^{1 *}$ (D), Alfredo Adolfo AYALA APONTE², José Fernando SOLANILLA DUQUE, \\ Héctor Samuel VILLADA ${ }^{1}$
}

\begin{abstract}
Traditional packaging made from non-renewable compounds such as petroleum has a negative impact on the environment, which has led to a growing body of research on biodegradable packaging. This paper details the characterization of a biocomposite which was made from cassava bran, coffee husk, and water (BCCW). After this, a layer of polylactic acid (PLA) was added, mixed with nisaplin 1000UI, and 8, 10,12\% concentrations of oregano (Origanum vulgare L) essential oil (OVEO) in order to create an active biocomposite $(\mathrm{AB})$ which could be used as an antimicrobial material in the packaging of pork. In vitro inhibitory effects were evaluated against Listeria monocytogenes, Escherichia coli and Salmonella typhimurium. After obtaining the active biocomposite, the characterization was performed by means of Infrared Spectroscopy (FT-IR), Water Vapor Permeability (WVP), a Mechanical Property analysis, Differential Scanning Calorimetry (DSC), and Scanning Electron Microscopy (SEM). Using the concentration with the highest inhibition against pathogenic bacteria, antimicrobial tests were carried out after the application of the $\mathrm{AB}$ in pork meat for $0,1,3,5$, and 10 days. Inhibition tests against pathogenic bacteria showed that nisin had a greater effect on Gram positive bacteria, while OVEO had an effect on both Gram positive and Gram negative bacteria. FT-IR analysis allowed for the characterization of the molecular interactions of OVEO and nisin in the matrix compounds of the different biocomposites by identifying and interpreting their respective vibration bands. According to the statistical analysis, the different concentrations of the biocomposites affect WVP $(\mathrm{p}<0.05)$. BCCW showed the highest permeability to water vapor, whereas the other treatments did not show significant differences. The mechanical properties test of the AB showed that the different treatments had a significant effect $(\mathrm{p}<0.05)$ on the maximum flexural strength and flexural modulus. These values decreased with the application of the PLA layer, the concentrations of the biocomposites did not have a significant maximum deformation effect ( $p>0.05$ ). The DSC test on the ABs showed two melting peaks and an increase in the glass transition temperature (Tg) of the PLA, a finding that indicates greater thermal stability in the ABs. SEM images revealed that the nisaplin and OVEO particles were uniformly distributed in the PLA polymer matrix on the surface of the ABs. The ABs showed a significant reduction in Listeria monocytogenes in pork as of day 3 and in the other pathogens as of the 10th day. The biocomposite containing OVEO and nisaplin, showed good potential to be used to food packaging.
\end{abstract}

Keywords: active packaging; antimicrobial; alimentary pathogens; renewable materials; nisin.

Practical Application: Biocomposite from cassava bran, coffee husk and PLA enriched with nisaplin and OVEO was developed; The AB inhibited both Gram-positive and Gram-negative food borne pathogens; Polylactic acid (PLA) layer played the role to maintaining the antimicrobial activity of OVEO, nisaplin and improved barrier properties of the biocomposite; WPV of AB (PLA/Nisin/OVEO) was lower than that of BCCW; The mechanical proprieties of AB were inferior to those found in BCCW; Biocompuesto contained OVEO and nisaplin has good potential to be used as food packaging; The in vitro inhibition test revealed greater inhibition against pathogenic bacteria than the test carried out in pork; The DSC test revealed that the PLA/ Nisin/OVEO layer led to an increase in the glass transition temperature.

\section{Introduction}

Consumer concern caused by improper disposal of plastic waste and limited resources in the petrochemical industry has led to the research and development of biodegradable options as alternatives to conventional plastic materials, e. g. the production of biocomposites, using the combination of a renewable, biodegradable polymer with a natural fiber and a starch polymer shows a promising, sustainable alternative to petroleum-based plastics. In addition, the use of natural fibers as fillers opens the way for added value to food waste, thereby reducing the global impact of the food production cycle (Sánchez-Safont et al., 2018). The addition of antimicrobial compounds provides further advantages for the packaging of 
perishable food. One important reason for innovation in food packaging industry is the increasing problem of foodborne microbial outbreaks. These necessitate the use of packaging that offers antimicrobial effects and is able to assist in food quality maintenance (Majid et al., 2016). Health risks associated with fresh and processed meats have prompted research on microbial growth reduction, by various means.

Active packaging is an important area of research, as it can help control the conditions under which meat is most commonly stored, i.e. during cold storage, distribution, and sale. The use of active packaging has been estimated to potentially reduce meat losses, at the retail level, by 147,600 t/year in the EU alone, with further reductions achievable with the extension of this effect to the consumption stage (Zhang et al., 2015a). In general, antimicrobial agents can be applied directly to product surfaces, but this entails a high degree of compound migration into the product. Oregano (Origanum vulgare L) essential oil, one antimicrobial agent, has a poor water solubility and decomposes easily as it reacts with many natural food nucleophiles, such as amines, amino acids, proteins, alcohols, and sulphites. This either limits its effectiveness in the proximity of its application or generates volatile substances in headspace (Li et al., 2012b). The addition of nisin or OVEO to biodegradable materials has had an effect on pathogenic bacteria (Ketkaew et al., 2018; Li et al., 2012a) on the entire exposed product surface. This is generally sufficient, in the case of meat, since the interior can be assumed to be sterile. There is also a reduced migration of additive into the product, which, in some cases, may be of sensory or regulatory interest (Schumann \& Schmid, 2018). As with plastic containers, conventional industrial engineering processes are often used to manufacture antimicrobial, biodegradable packaging, which include extrusion molding, blown extrusion, injection molding, thermoforming, or other combinations However, thermal and mechanical processing of plastic packages can lead to the inactivation or destruction of antimicrobial agents, due to polymer fragmentation and bond splitting, which leads to depolymerization. Likewise, the use of cellulosic waste and agricultural by-products in packaging as a source of sustainable fillers, represents an attractive and sustainable means of added value. These by-products are attractive due to their natural abundance, low density, high specific modulus, and biodegradability, however, their high hydrophilicity and thermal instability are the main drawbacks for their application as plastic fillers (George et al., 2016). These phenomena explain the challenges related to research on the incorporation of antimicrobial compounds into biodegradable matrices.

The PLA is obtained by controlled depolymerization of the lactic acid monomer, from the fermentation of raw materials, such as sugar, corn, and other such renewable, easily-biodegradable resources (Guo et al., 2014). It is similar to conventional petrochemical plastics, good water vapor barriers, with relatively low gas transmittance (Gan \& Chow, 2018).

Zhou et al. (2019) have shown that the addition of a hydrophobic Polylactic Acid (PLA) layer over a hydrophilic starch biopolymer can improve its mechanical and barrier properties, and also prevent thermal processes from degrading the antimicrobial compounds. Sensitive compounds such as nisin and OVEO have been studied in cold conditions using the casting method (Jin et al., 2010b; Salmieri et al., 2014b; Silveira et al., 2020), solvents and ultrasonic treatment (Woraprayote et al., 2018), and emulsion films (Zhu et al., 2018). The development of biocomposites with the addition of natural antimicrobial agents such as nisin, lysozyme, oregano essential oil, and other natural extracts (Syafiq et al., 2020), have shown inhibitory effects against selected microorganisms such as L. monocytogenes (Salmieri et al., 2014a; Shiroodi et al., 2016), Escherichia coli (Kwiatkowski et al., 2016), Staphylococcus aureus (Wen et al., 2016) and Micrococcus lysodeikticus (Jbilou et al., 2014).

In front of the presented the main objective of this research paper was to develop an active biocomposite using natural fibers and a layer of PLA/OVEO/nisin, and then characterize its properties and test its effect on typical pathogenic bacteria in pork meat.

\section{Materials and methods}

\subsection{Materials}

The cassava bran was supplied by Clayuca Inc. (Palmira, Colombia), and had a dry base humidity of $12 \% \pm 2$, and had been sieved at $250 \mu \mathrm{m}$. The coffee husk was collected from the Tecnicafé coffee technology park, and had been processed in a hammer/blade mill (Penagos, TP8, Colombia) and sieved to a size of smaller than $425 \mu \mathrm{m}$, with humidity between 10 and 13\%. Polylactic acid (PLA 2002D, Carguill Dow Polymers LLC, USA) is a white, biodegradable aliphatic polyester that is obtained in pellet form, type $\mathrm{L}(-)$ of high molecular weight $(120,000 \mathrm{~g} / \mathrm{mol})$. Analytical grade methylene chloride, nisaplin (Danisco, USA) and commercial OVEO (Now Foods, USA) were used. The microorganisms used - Salmonella typhimurium ATCC 14028, Escherichia coli ATCC 25922, and L. monocytogenes ATCC 51742 - were obtained from the von Humboldt gene bank of the Microbiology and Applied Biotechnology research group (MIBIA) at the Universidad del Valle (Cali, Colombia).

\subsection{Obtention of the BCCW}

A mixture of water (45\%), cassava bran $(40 \%)$, and coffee husk (15\%) was prepared in order to create the BCCW. The quantities of each component were accordingly weighed and mixed for 10 minutes, as described in patent number CO2018014376A1 (Villada et al., 2020).

\subsection{Development of the BCCW with the added PLA layer and antimicrobial compounds}

The coatings were prepared with 1,000 mg of PLA, $1 \mathrm{mg}$ of nisin (1000 IU) and 8, 10 and 12\% of OVEO. Six biocomposites were obtained, $\mathrm{ABO}$ : Active biocomposite/oil; $\mathrm{ABN}$ : Active biocomposite/nisaplin; ABNO1: Active biocomposite/nisaplin/ oil; ABNO2: Active biocomposite/nisaplin/oil; ABNO3: Active biocomposite/nisaplin/oil; BCCW: Biocomposite/cassava/coffee/ water. Table 1 shows all the treatments used in the study. The nisin concentration was established in preliminary studies, considering Govaris et al. (2010), while the OVEO contents were based on concentrations evaluated by Requena et al. (2019). The PLA resin 
Table 1. Treatments used to obtain AB.

\begin{tabular}{cccc}
\hline Sample & Biocomposite & Nisaplin $\left(\mathrm{UI} / \mathrm{cm}^{2}\right)$ & OVEO $\left(\mu \mathrm{L} / \mathrm{cm}^{2}\right)$ \\
\hline Oregano $130 \mu \mathrm{L}$ & ABO & - & 17.33 \\
nisaplin 1000UI & ABN & 133.33 & - \\
nisaplin $1000 U I+$ OVEO $100 \mu \mathrm{L}$ & ABNO1 & 133.33 & 13.33 \\
nisaplin $1000 U I+$ OVEO $125 \mu \mathrm{L}$ & ABNO2 & 133.33 & 16.33 \\
nisaplin $1000 U I+$ OVEO $150 \mu \mathrm{L}$ & ABNO3 & 133.33 & 20 \\
Biocomposite Control & BCCW & - & - \\
\hline
\end{tabular}

ABO: Active biocomposite/oil; ABN: Active biocomposite/nisaplin; ABNO1: Active biocomposite/nisaplin/oil 1; ABNO2: Active biocomposite/nisaplin/oil 2; ABNO3: Active biocomposite/nisaplin/oil 3; BCCW: Biocomposite/cassava/coffee/water.

layer and antimicrobial compounds, were produced using the casting method, in accordance with the method used by Jin et al. (2010a), $15 \mathrm{~mL}$ of methylene chloride was added to a beaker containing the precipitate, and this wasmixed for $30 \mathrm{~min}$. At the end of this time, the mixture obtained was poured onto BCCW samples of $1.5^{\star} 5 \mathrm{~cm}$ and $1.74 \pm 0.06 \mathrm{~mm}$ thick. The coated BCCW material was left at $30^{\circ} \mathrm{C}$ in a convection oven (Binder FD 260, Germany), for $4 \mathrm{~h}$, until the solvent evaporated.

\subsection{Inoculum preparation with pathogenic bacteria}

The lyophilized strains of Salmonella typhimurium, Escherichia coli, and Listeria monocytogenes were supplied by the Colombian Collection of Type Cultures (ATCC, Universidad del Valle, Colombia), and were stored at $-25^{\circ} \mathrm{C}$ with $30 \%$ glycerol. In the exponential growth phase, the bacterial cultures were prepared by inoculating the microbial stock suspensions in Nutrient Broth (NB), followed by incubation at $35^{\circ} \mathrm{C}$ for $12 \mathrm{~h}$, in order to obtain bacterial suspensions of 5-6 log colony forming units (CFU)/mL.

\subsection{In vitro inhibition test}

The inhibition test was carried out in accordance with the adjusted methodology described by Guo et al. (2014). The $1.5^{\star} 5 \mathrm{~cm}^{2} \mathrm{AB}$ samples with the five different OVEO concentrations were placed in $100 \mathrm{~mL}$ Erlenmeyer flasks, with $45 \mathrm{~mL}$ of NB. The tubes were immediately inoculated with the pathogenic bacteria cultures prepared previously, at a final concentration of 5-6 log CFU/mL. The NB tubes were incubated at $30^{\circ} \mathrm{C}$ for $24 \mathrm{~h}$, and in sequence shaken at $100 \mathrm{rpm}$. To determine populations in the NB following incubation, serial dilutions of the resulting bacterial suspensions were made, in water with $0.1 \%$ peptone, and dispersed $100 \mu \mathrm{L}$ in petri dishes of listeria chromogenic agar, with the selective supplements X072 and X010 (Harlequin, United States) for Listeria, Salmonella Shigella (Sharlau, Spain) for Salmonella, and Colinstant Chromogenic Agar (Sharlau, Spain) for E. coli. All samples were then incubated at $37^{\circ} \mathrm{C}$, for up to $24 \mathrm{~h}$, and CFUs were then counted.

\subsection{Physical and chemical characterization of active biocomposite}

Fourier transform infrared spectroscopy (FT-IR) with attenuated total reflectance (ATR)

The films were analyzed using FT-IR with an ATR accessory. The experiments were carried out following the ASTME1252 (American
Society for Testing and Materials, 2013) standard. FT-IR spectra were obtained on an Iraffinity-1S FT-IR spectrometer (Shimadzu, Inc., Shelton CT, Japan), with a deuterated triglycine sulfate (DTGS) detector. Biocomposite samples were studied in an ATR MIRacle 10 fixture (Shimadzu, Inc., Shelton CT, Japan) with a single reflection diamond crystal at an angle of incidence of $45^{\circ}$. The spectrum of each sample was obtained by taking the average of 45 scans at a resolution of $4 \mathrm{~cm}^{-1}$ at $25^{\circ} \mathrm{C}$. A Happ-Genzel apodization was used, with a magnitude phase correction. A flat tip was used to achieve an intimate contact between the sample and the crystal, without pressure control (Nicolet Protege 460 Magna IR Thermo Scientific, USA).

\section{Water vapor permeability test}

Water vapor permeability (WVP) was determined following the gravimetric technique established by the ASTM E96-05 (American Society for Testing and Materials, 2005). The samples were first conditioned in a hermetically sealed glass container $(0 \% \mathrm{RH})$. After conditioning and weighing them, the samples were deposited inside cylindrical permeation cells, in direct cell-sample contact, and these were then placed inside the hermetic container that maintained a constant $50 \% \mathrm{RH}$ at $23^{\circ} \mathrm{C}$ throughout the course of the experiment. Water vapor permeability $(\mathrm{P})$ was calculated with Equations 2, 3 and 4, using the fundamental equation for flux (Equation 1). The flux, or Water Vapor Transmission Rate (WVTR), was calculated with the slope $(\mathrm{G})$ of the linear regression between the variation in sample weight against time, the equations used for these calculations were:

$$
\begin{aligned}
& \text { Flux }=\frac{\left(P^{*} \Delta P\right)}{l} \\
& P=\frac{(W V T R \times l)}{\Delta P} \\
& \text { WVTR }=\frac{G}{A}
\end{aligned}
$$

$\Delta P=S \times(R 1-R 2)$

where " $\mathrm{P}$ " is permeability, " $\Delta \mathrm{P}$ " corresponds to the variation of the partial pressures, inside and outside the permeation cell, "l" is the thickness of the sample, "A" is the area exposed to the transmission of water vapor, "S" is the saturation pressure of 
the vapor at the test temperature, "R1" is the fraction of relative humidity generated by the saturated saline solution, and "R2" that provided by the silica gel inside the permeation cell.

\section{The mechanical properties}

The mechanical properties were evaluated in accordance with technical standard ASTM D790-10 (American Society for Testing and Materials, 2010), and certain modifications, using a $500 \mathrm{~N}$ load cell. Samples with dimensions of $127 \mathrm{~mm}$ (length), $12.7 \mathrm{~mm}$ (width), and $3.2 \mathrm{~mm}$ (thickness), were calibrated with a digital Vernier caliper (CD-6"CSX-B Mitutoyo, Brazil). The test was carried out with a universal test kit (EZ-L Shimadzu, Japan). The samples were held on two supporting structures, located under the ends of the samples. Next, a bending force was applied to sample centers, until they fractured. Five samples were evaluated per titrated treatment. Before testing, the samples were conditioned for eight days, at a relative humidity of $50 \pm 5 \%$ and $23 \pm 2{ }^{\circ} \mathrm{C}$ (American Society for Testing and Materials, 2008). Results of maximum flexural strength $(\mathrm{MPa})(\sigma \mathrm{f})$, maximum deformation (\%) (ef), and elastic modulus (MPa) (EB) were obtained.

\section{Differential scanning calorimetry (DSC).}

The DSC was carried out in accordance with the ASTM D3418-08 (American Society for Testing and Materials, 2008) standard. Each specimen, of approximately $10 \mathrm{mg}$, was previously conditioned at a relative humidity of $50 \%$ and a temperature of $23{ }^{\circ} \mathrm{C}$. The sample was placed inside an aluminum capsule, sealed, and placed inside the DSC thermal chamber. A first heating cycle, from room temperature to $190^{\circ} \mathrm{C}$, was performed to clear the thermal history at a heating rate of $10^{\circ} \mathrm{C} / \mathrm{min}$, followed by an isotherm of $190{ }^{\circ} \mathrm{C}$ for five minutes. A cooling cycle was then carried out, from $190^{\circ} \mathrm{C}$ to $-80^{\circ} \mathrm{C}$, at a cooling rate of $20^{\circ} \mathrm{C} / \mathrm{min}$ and an isotherm of $-80^{\circ} \mathrm{C}$ for five minutes. Finally, a heating cycle, from $-80^{\circ} \mathrm{C}$ to $200^{\circ} \mathrm{C}$, was carried out, in order to determine the glass transition $(\mathrm{Tg})$ and melting temperatures $(\mathrm{Tm})$ for each samples. A calorimeter (model Q20, TA Instruments, USA) was used for this experiment. The degree of crystallinity $\left(\mathrm{X}_{C}\right)$ was determined in accordance with the following Equation 5.

$X_{C}=\left(\frac{\Delta H}{\Delta H_{m}^{\circ} \times\left(1-\frac{\% w t B C C W}{100}\right)}\right) \times 100$

where $\Delta H=\Delta H m$ (for the second heating curve), $\Delta H_{m}^{\circ}$ is the enthalpy of fusion of the crystalline polymer matrix, at $100 \%$ ( $93.0 \mathrm{~J} / \mathrm{g}$ for PLA), and \%wt BCCW (biocomposite) is the percentage, in weight, of the bran and husk (Battegazzore et al., 2014).

\section{Scanning electron microscopy (SEM) morphometry}

Samples measuring $2 \times 2 \mathrm{~cm}$ were used for the morphological analysis, adhering to the method described by Navia-Porras et al. (2015), whit some modifications. These were kept at a Relative Humidity (RH) of $50 \%$ and a temperature of $23{ }^{\circ} \mathrm{C}$. Using a vacuum coating equipment [Denton Vaccum Desk IV], a 50 millitorr gold bath was performed in two positions: a) sitting on the circular base for $150 \mathrm{~s}$, and b) tilted for $50 \mathrm{~s}$. The goldcoated samples were placed in a sample holder in the microscope chamber (JSM 6490 LV JEOL, Japan) at a vacuum of $30 \mathrm{~Pa}$. As the vacuum stabilized, the tungsten filament was turned on, with an acceleration power of $15 \mathrm{kV}$.

\section{Test of inhibition in pork.}

Inhibition assessment was performed as described by Salmieri et al. (2014a) with some modifications. Each sample of raw pork $(2 \mathrm{~g})$ was inoculated with $0.2 \mathrm{~mL}$ of $5-6 \log \mathrm{UFC} / \mathrm{mL}$ separately (the inoculum was prepared as described in section 2.4) with each of the $S$ typhimurium, E. coli and L. monocytogenes strains and spread evenly with a sterile glass rod. These were left in an environmental chamber for 30 minutes. They were then placed between the $A B$ and a PLA layer with-antimicrobials, in order to ensure contact with the meat on both sides. They were then inserted into high-barrier packaging bags and vacuum sealed using a sealing machine set at $90 \%$ vacuum. Independent batches were packed on each sample day, using: (1) control (meat only) and (2) meat with PLA-oregano essential oil-nisin biocomposite. After packaging, all batches were stored at $4{ }^{\circ} \mathrm{C}$, and sampling was carried out at $0,1,3,5$ and 10 days. On each selected day, the raw pork samples that were wrapped were carefully removed from the $A B$ and the meat samples were then diluted in the proportion of $2 \mathrm{~g}$ part in $18 \mathrm{~mL}$ of sterile peptone water $(0.1 \%$ w/v; Difco, Becton-Dickinson). The solution was homogenized for 2 minutes at $260 \mathrm{rpm}$ and $100 \mu \mathrm{L}$ of the appropriate dilution was seeded in a Listeria Chromogenic Agar petri dish, with the aforementioned supplements, selective for Salmonella, Listeria and Escherichia. The petri dishes were incubated for 24 hours at $35^{\circ} \mathrm{C}$, the CFUs were counted and expressed as log CFU/g of pork.

\section{Experimental design and stadistical analysis}

The effect of the independent variables on the responses was studied through a one factor design, which was the Nisaplin and OVEO concentration. A statistical analysis of the results was performed through ANOVA for a level of significant $(\alpha)$ of 0.05 followed by a Tukey post hoc. All statistical analysis was performed using the Minitab program (V 18).

\section{Results and discussion}

\subsection{Effects of treatments on L. monocytogenes, E. coli, and S. typhimurium cell counts}

In accordance with the analysis of variance, all antimicrobial concentrations in the treatments had significant influences $(\mathrm{p}<0.05)$ on the growth inhibition of the three pathogenic bacteria, after $24 \mathrm{~h}$. Figure 1 shows the inhibition effect of the mixture of nisaplin and OVEO. ABNO3 treatment showed strong inhibition, with counts close to zero log after 24 hours of incubation. L. monocytogenes, E. coli, and S. typhimurium, in control samples, grew at $8,8.5$, and $10.2 \log \mathrm{CFU} / \mathrm{mL}$, respectively, after $24 \mathrm{~h}$. 
The ABN treatment using only nisaplin had no effect on the Gram negative bacteria (S. typhimurium and E. coli), as their cell wall membrane contains Lipids, Proteins, and lipopolysaccharides that provide effective protection against biocides such as nisin (Jin \& Zhang, 2008; Li et al., 2018). Similar results were obtained by Santos et al. (2018) and Li et al. (2012b). In the case of L. monocytogenes, (Gram positive bacteria), there was a reduction of almost $3 \mathrm{Log}$, compared to the control. The activity of nisin on Gram positive bacterial cells occurs through two mechanisms. The first occurs when nisin targets the cytoplasmic membrane and increases the permeability of the membrane through the formation of pores, causing the exit of intracellular material, which causes the cells to run out of energy needed to carry out biosynthetic processes (Cleveland et al., 2001). In the second mechanism, nisin reaches the cytoplasmic membrane of the bacterium and forms a pyrophosphate cage which involves the first two rings of nisin and the rest of pyrophosphate of lipid II through hydrogen bonds. (Hasper et al., 2006).

Many studies have demonstrated the capacity of nisin to inhibit the microbial growth of gram positive bacteria, including the highly pathogenic bacteria found in food, such as Staphylococcus aureus (Godoy-Santos et al., 2019), Staphylococcus epidermidis (Fael \& Demirel, 2020), Clostridium botulinum (Gharsallaoui et al., 2016), and L. monocytogenes (Bastarrachea et al., 2010), among other pathogenic microorganisms (Nakazato et al., 2017).

Unlike the biocomposites using only nisaplin, which did not have an effect on Gram negative bacteria, the biocomposites supplemented with OVEO had a significant effect on the three pathogenic bacteria studied. It follows that the antimicrobial action on S. typhimurium and E.coli, in biocomposites ABNO1, $\mathrm{ABNO} 2$, and $\mathrm{ABNO} 3$ can be attributed to addition of OVEO.

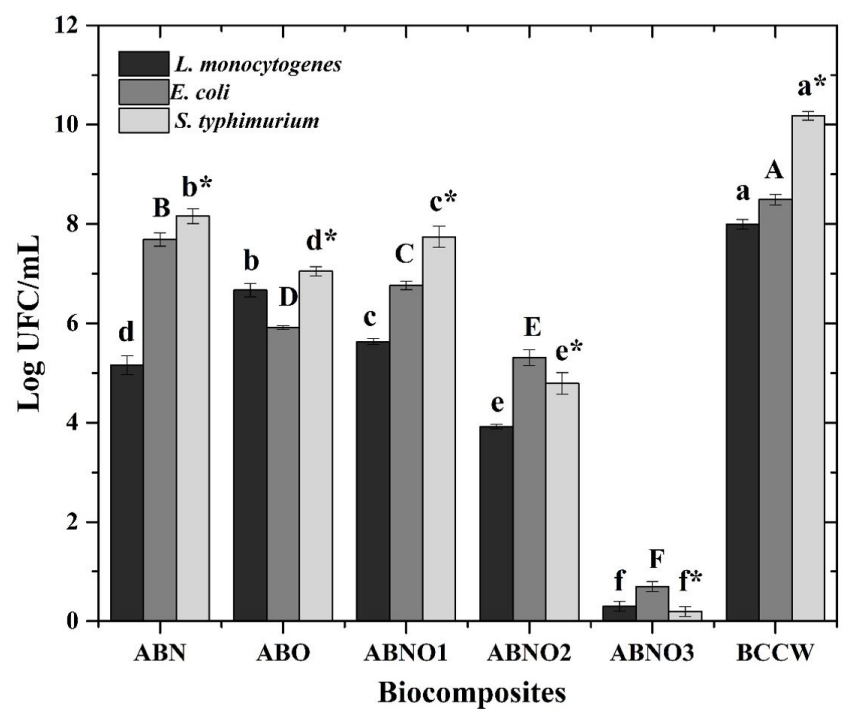

Figure 1. Colony forming units (CFU) of L. monocytogenes, E. coli and $S$. typhimurium in the biocomposites. Values are \pm standard deviation of three replicates. Different capital letters are significantly different $(\mathrm{P}<0.05)$ E. coli inhibition. Lowercase letters are significantly different $(\mathrm{P}<0.05)$ S. typhimurium inhibition. Lowercase letters with *are significantly different $(\mathrm{P}<0.05)$ L. monocytogenes inhibition.
The mechanism of action OVEO has not yet been fully established. However, studies have shown that compounds of different chemical groups found in these natural products can generally act on permeabilization or disruption of the cytoplasmic membrane, allowing for the passage of non-specific compounds, or the release of cytoplasmic content, respectively (Zhang et al., 2015b). Furthermore, compounds such as eugenol and carvacrol, present in OVEO, can inhibit the ATPase enzyme, which is responsible for the generation of energy in the cell, leading to cell death in Gram positive and Gram negative bacteria. However, the greater hydrophobicity of the E. coli surface may explain greater sensitivity to OVEO, as compared to Gram positive bacteria, since greater hydrophobicity facilitates the interaction of the OVEO with the membrane (Gill \& Holley, 2006), allowing for the separation of lipids from the cell membrane and mitochondria. This separation causes disorders in cell structure, which make it more permeable and susceptible to ions (Oosterhaven et al., 1995). Studies of biocomposites incorporated with OVEO report inhibition against Gram positive and negative bacteria, (Caetano et al., 2017; Cruz-Tirado et al., 2020; Ketkaew et al., 2018).

\subsection{Fourier transform infrared spectroscopy with attenuated total reflectance (FT-IR-ATR).}

FTIR spectra, in the near infrared region of $3650-2750 \mathrm{~cm}^{-1}$ were identified for all biocomposites and bands as shown in Table 2. FTIR spectra, with a focus on the $1800-700 \mathrm{~cm}^{-1}$ region of ABNO3, BCCW, pure PLA, and OVEO, can be seen in Figure 2. The first step in this process was to characterize the incorporation of OVEO into the matrix of the $\mathrm{ABNO} 3$ biocomposite - the treatment selected for packing the pork samples and identify the infrared bands and interactions related to the OVEO-PLA-AB matrix. A strong absorption band was observed at $1756 \mathrm{~cm}^{-1}$, due to the $\mathrm{C}=\mathrm{O}$ stretching (Molinaro et al., 2013).

The bending vibrations, at 1444 and $1360 \mathrm{~cm}^{-1}$, are related to asymmetric and symmetric deformations of the $\mathrm{CH}_{3}$-group (Hossain et al., 2012). The $1181 \mathrm{~cm}^{-1}$ can be attributed to C-O-C

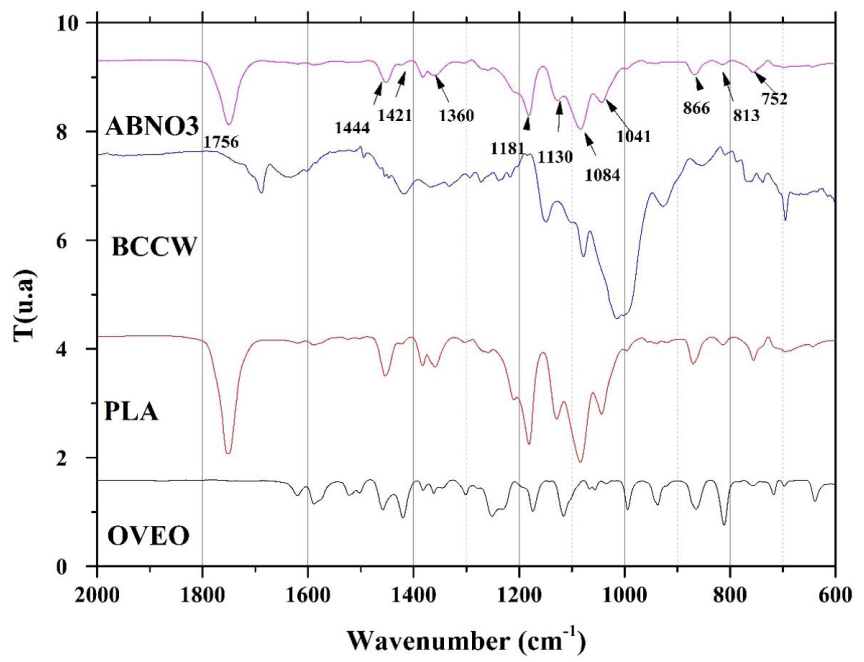

Figure 2. Espectros FT-IR de los biocompuestos activos centrados en la región 1800-700 $\mathrm{cm}^{-1}$. 
Table 2. Characteristic bands of the infrared spectrum of Active Biocomposites.

\begin{tabular}{|c|c|c|c|c|c|c|c|c|c|c|c|}
\hline \multicolumn{2}{|c|}{$\mathrm{ABN}$} & \multicolumn{2}{|c|}{$\mathrm{ABO}$} & \multicolumn{2}{|c|}{ ABNO1 } & \multicolumn{2}{|c|}{$\mathrm{ABNO} 2$} & \multicolumn{2}{|c|}{ ABNO3 } & \multicolumn{2}{|c|}{ BCCW } \\
\hline $\mathrm{cm}^{-1}$ & Band & $\mathrm{cm}^{-1}$ & Band & $\mathrm{cm}^{-1}$ & Band & $\mathrm{cm}^{-1}$ & Band & $\mathrm{cm}^{-1}$ & Band & $\mathrm{cm}^{-1}$ & Band \\
\hline 813 & $-\mathrm{OH}$ & 813 & $-\mathrm{OH}$ & 813 & $-\mathrm{OH}$ & 813 & $-\mathrm{OH}$ & 813 & $-\mathrm{OH}$ & 813 & $-\mathrm{OH}$ \\
\hline 1041 & $\mathrm{C}-\mathrm{O}$ & 1041 & $\mathrm{C}-\mathrm{O}$ & 1041 & $\mathrm{C}-\mathrm{O}$ & 1041 & $\mathrm{C}-\mathrm{O}$ & 1041 & $\mathrm{C}-\mathrm{O}$ & 1041 & $\mathrm{C}-\mathrm{O}$ \\
\hline 1084 & $\mathrm{C}-\mathrm{O}$ & 1084 & $\mathrm{C}-\mathrm{O}$ & 1084 & $\mathrm{C}-\mathrm{O}$ & 1084 & $\mathrm{C}-\mathrm{O}$ & 1084 & $\mathrm{C}-\mathrm{O}$ & 1084 & $\mathrm{C}-\mathrm{O}$ \\
\hline 1130 & $\mathrm{C}-\mathrm{O}$ & 1130 & $\mathrm{C}-\mathrm{O}$ & 1130 & $\mathrm{C}-\mathrm{O}$ & 1130 & $\mathrm{C}-\mathrm{O}$ & 1130 & $\mathrm{C}-\mathrm{O}$ & 1130 & $\mathrm{C}-\mathrm{O}$ \\
\hline 1181 & $\mathrm{C}-\mathrm{O}-\mathrm{C}$ & 1181 & $\mathrm{C}-\mathrm{O}-\mathrm{C}$ & 1181 & $\mathrm{C}-\mathrm{O}-\mathrm{C}$ & 1181 & $\mathrm{C}-\mathrm{O}-\mathrm{C}$ & 1181 & $\mathrm{C}-\mathrm{O}-\mathrm{C}$ & 1181 & $\mathrm{C}-\mathrm{O}-\mathrm{C}$ \\
\hline 1364 & $-\mathrm{CH} 3$ & 1360 & $-\mathrm{CH} 3$ & 1359 & -CH3 & 1360 & $-\mathrm{CH} 3$ & 1360 & -CH3 & 1365 & $-\mathrm{CH} 3$ \\
\hline 1421 & - & 1417 & $-\mathrm{OH}$ & 1415 & $-\mathrm{OH}$ & 1415 & $-\mathrm{OH}$ & 1419 & $-\mathrm{OH}$ & 1421 & - \\
\hline 1441 & $-\mathrm{CH} 3$ & 1444 & $-\mathrm{CH} 3$ & 1444 & $-\mathrm{CH} 3$ & 1444 & $-\mathrm{CH} 3$ & 1443 & $-\mathrm{CH} 3$ & 1454 & $-\mathrm{CH} 3$ \\
\hline 1618 & $\mathrm{C}=\mathrm{O}$ & 1618 & - & 1620 & $\mathrm{C}=\mathrm{O}$ & 1614 & $\mathrm{C}=\mathrm{O}$ & 1617 & $\mathrm{C}=\mathrm{O}$ & 1618 & - \\
\hline 1587 & $\mathrm{~N}-\mathrm{H}$ & 1587 & - & 1541 & $\mathrm{~N}-\mathrm{H}$ & 1579 & $\mathrm{~N}-\mathrm{H}$ & 1563 & $\mathrm{~N}-\mathrm{H}$ & 1587 & - \\
\hline 1751 & $\mathrm{C}=\mathrm{O}$ & 1756 & $\mathrm{C}=\mathrm{O}$ & 1756 & $\mathrm{C}=\mathrm{O}$ & 1754 & $\mathrm{C}=\mathrm{O}$ & 1756 & $\mathrm{C}=\mathrm{O}$ & 1758 & - \\
\hline
\end{tabular}

stretching of PLA (Molinaro et al., 2013). The peaks, at 1130, 1084 , and $1041 \mathrm{~cm}^{-1}$ may correspond to C-O stretching vibrations (Pamuła et al., 2001), while the bands detected at 866 and $752 \mathrm{~cm}^{-1}$ (far infrared) can be assigned to the amorphous and crystalline phases of the PLA layer, respectively (Agrawal, 2010). The peak, at $1421 \mathrm{~cm}^{-1}$, appeared as a result of bending in the -OH plane of the carvacrol and thymol phenolic compounds (Pola et al., 2016), which change area as OVEO concentrations increase. Finally, the peak, at $813 \mathrm{~cm}^{-1}$, is in accordance with the out-of-plane - $\mathrm{OH}$ curvature in di- and tri-substituted herb compounds, such as carvacrol, thymol, and their derived terpenes and terpenic alcohols (Salmieri et al., 2014b).

The peaks at 3332 and $1645 \mathrm{~cm}^{-1}$ were used to identify the presence of the cassava bran, coffee husks, and BCCW, which were attributed to the stretching and bending of water and $\mathrm{O}-\mathrm{H}$, respectively. The adsorption band at $2918 \mathrm{~cm}^{-1}$ was assigned to C-H stretch, (Matsuda et al., 2013). The characteristic peaks of coffee husks were due to the presence of lignin, cellulose, and hemicellulose. The broad bands at 3336 and $2926 \mathrm{~cm}^{-1}$ were assigned to the $\mathrm{O}-\mathrm{H}$ group and $\mathrm{C}-\mathrm{H}$ group, respectively. The peaks at $1700 \mathrm{~cm}^{-1}$ were related to hemicellulose $\mathrm{C}=\mathrm{O}$. Those at 1426 and $1236 \mathrm{~cm}^{-1}$ were assigned to $\mathrm{C}-\mathrm{H}_{2}$ and $\mathrm{C}-\mathrm{O}-\mathrm{C}$ of the cellulose chain. The band at $1148 \mathrm{~cm}^{-1}$ was due to the asymmetric deformation of C-O-C of cellulose and hemicellulose (Mothé \& Miranda, 2009).

The incorporation of nisin into the matrix of the biocomposite, identified with the peaks at 1618 and $1587 \mathrm{~cm}^{-1}$, is mainly due to the bands of Amide I (bond stretching vibration $\mathrm{C}=\mathrm{O}$ ) and Amide II (bending vibration of the N-H bonds) (Shiroodi et al., 2016) respectively, both related to the peptide bond. Other authors have reported similar observations, related to the nisin peptide bond (Salmieri et al., 2014a).

\subsection{The water vapor permeability test (WVP)}

The WVP values of the BCCW and biocomposites with PLA and antimicrobials are shown in Figure 3. In accordance with the analysis of variance, the different concentrations of biocomposites significantly affect $(\mathrm{p}<0.05)$ the WVP values. The Tukey test classifies the $\mathrm{ABO}, \mathrm{ABN}, \mathrm{ABNO} 1, \mathrm{ABNO} 2$, and

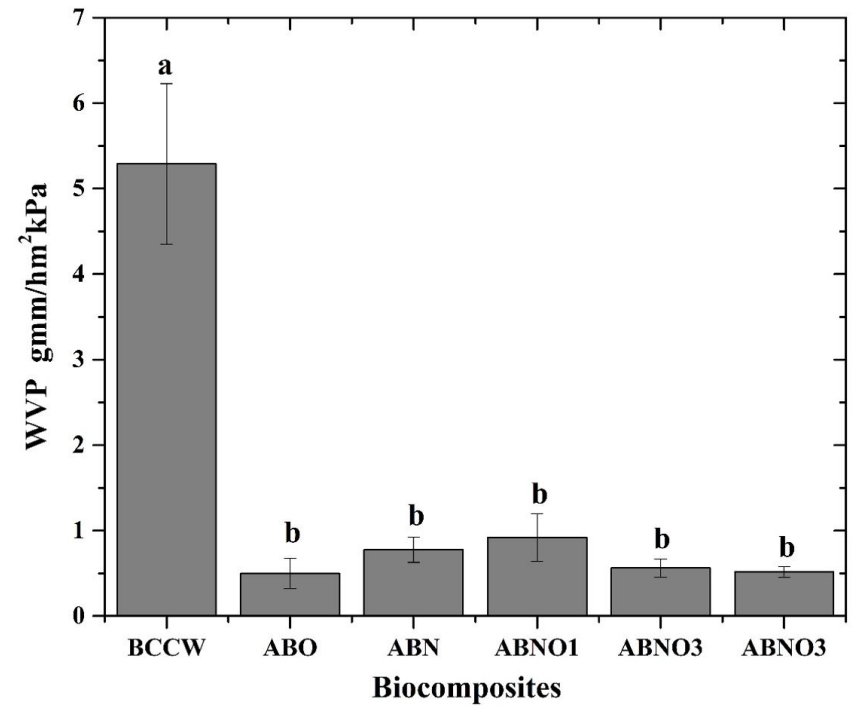

Figure 3. Values of WVP in biocomposites. Average value \pm standard deviation is reported. Different superscripts in each column indicate significant differences $(\mathrm{p}<0.05)$.

$\mathrm{ABNO} 3$ treatments into a single group - i.e. they do not present significant differences. Salmieri et al. (2014b) also reported that the addition of OVEO does not present significant differences from biocomposites made from PLA or cellulose particles.

The BCCW value was $5.29 \pm 0.1 \mathrm{gmm} / \mathrm{hm}^{2} \mathrm{kPa}$, while the other biocomposites varied between $0.581 \pm 0.404$ and $1.086 \pm$ $0.561 \mathrm{gmm} / \mathrm{hm}^{2} \mathrm{kPa}$. PLA is a highly hydrophobic resin, which can provide biocomposites with an effective barrier against water. In contrast, $\mathrm{BCCW}$ is composed of starch to a greater extent and has a highly hydrophilic polar structure. The structural polar groups act with water molecules, which penetrate the material, increasing polymer free volume, thus allowing the polymer chain segments to increase in mobility, causing WVP (Su et al., 2010).

In addition to the hydrophobic or hydrophilic nature of the polymer, the biocomposite's barrier properties are influenced by the presence of voids or cracks, compatibility of incorporated 
components, and steric hindrance in the film structure. Significant deviation may also be noted in the values attributed to the uneven material structure (Santosa \& Padua, 1999).

Ghanbarzadeh \& Oromiehi (2008), obtained WVP values of $0.1 \mathrm{gmm} / \mathrm{hm}^{2} \mathrm{kPa}$ for zein biocomposites coated with wax. Likewise, Salmieri et al. (2014b) obtained WVP values of $0.083 \mathrm{gmm} / \mathrm{hm}^{2} \mathrm{kPa}$ for biocomposites with added PLA and OVEO. In contrast, Cano et al. (2014) reported higher WVP values of $5.4 \pm 0.4 \mathrm{gmm} / \mathrm{hm}^{2} \mathrm{kPa}$ for biocomposites with rice bran, without the addition of any hydrophobic material to its polymeric structure.

\subsection{Mechanical properties}

The diverse biocomposite treatments had a significant influence $(\mathrm{p}<0.05)$ on maximum bending stress. Figure $4 \mathrm{~A}$ shows that the BCCW treatment resulted in the highest flexural stress value. According to Tukey's test, this is significantly different from other treatments. The $\mathrm{ABNO} 3, \mathrm{ABN}$, and $\mathrm{ABO}$ biocomposites did not show significant differences.

In Figures $4 \mathrm{~A}$ and $4 \mathrm{~B}$ can be observed that, in treatments with added PLA, there was a decrease in $\sigma_{\mathrm{f}}$ and $\mathrm{E}_{\mathrm{B}}$. This is corroborated by the decrease in crystallinity that occurred in the DSC test, this loss of crystallinity makes it possible to show the decrease in mechanical resistance in biocomposites with added PLA (Li et al., 2012a).

The reduction in maximum stress and flexural modulus may be due to the fact that the relationship between PLA and the thermoformed biocomposite is physical - i.e. the hydrophobicity of PLA does not allow for an anchoring in starch hydroxyl groups. In this vein, because the PLA is incorporated in dissolved form into the biocomposite, when it evaporates, the solvent may create steric hindrance and leave spaces within the polymeric matrix, which causes a decrease in maximum bending stress.

Huda et al. (2008), studied kenaf fibers with added PLA, and encountered a decrease in flexural strength. They showed that the properties of biocomposites made from PLA and kenaf fiber are a function of the matrix/fiber interfacial adhesion strength, which confirms that the compatibilization process is an effective strategy to increase the yields of polymer-based compounds. However, no chemical treatment was carried out during this study on the husks or bran fibers, in order to increase the anchoring of PLA layer. The different concentrations of the biocomposites did not have any effect on maximum deformation.

Figure $4 \mathrm{C}$ shows that the highest deformation values were found for $\mathrm{ABNO} 1$ and $\mathrm{ABNO} 2$, possibly due to enhanced molecule distribution or the OVEO's action as a plasticizer in the polymer matrix, which would allow for greater chain mobility, and consequently greater flexibility (Qin et al., 2017).

\subsection{Differential scanning calorimetry thermal properties}

The DSC curves of the samples of the PLA/BCCW active biocomposites (mixing ratio 0.25/0.5) and control samples (pure PLA and cassava bran) are shown in Figure 5. Three thermal events were observed during the analysis: $\mathrm{Tg}$ (Figure $5 \mathrm{a}$ ), and $\mathrm{Tm}_{1}$ and $\mathrm{Tm}_{2}$ (Figure $5 \mathrm{~b}$ ). $\mathrm{Tg}$ is associated with changes in the amorphous

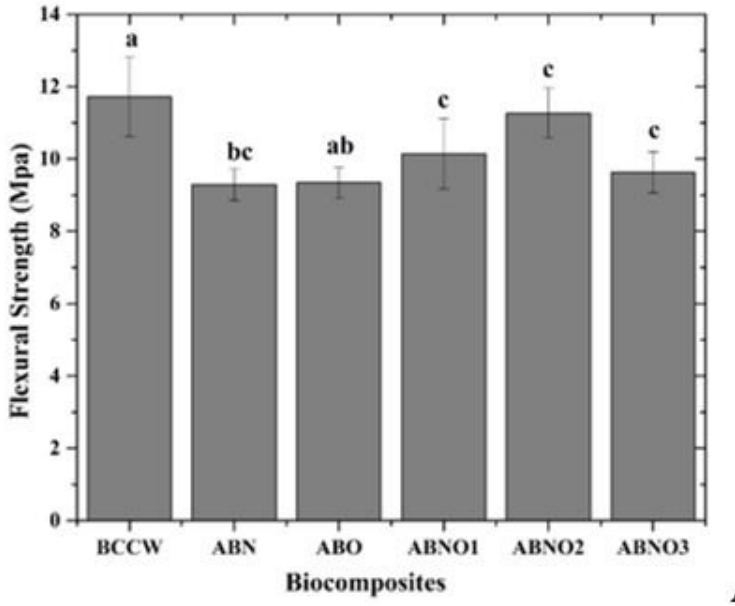

A

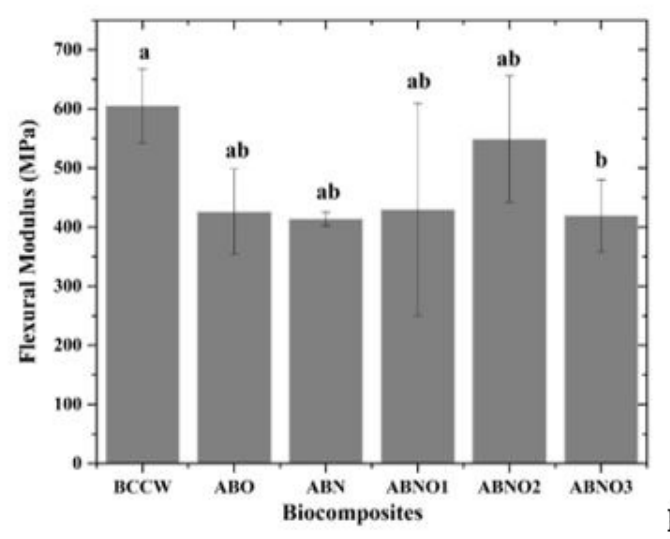

B

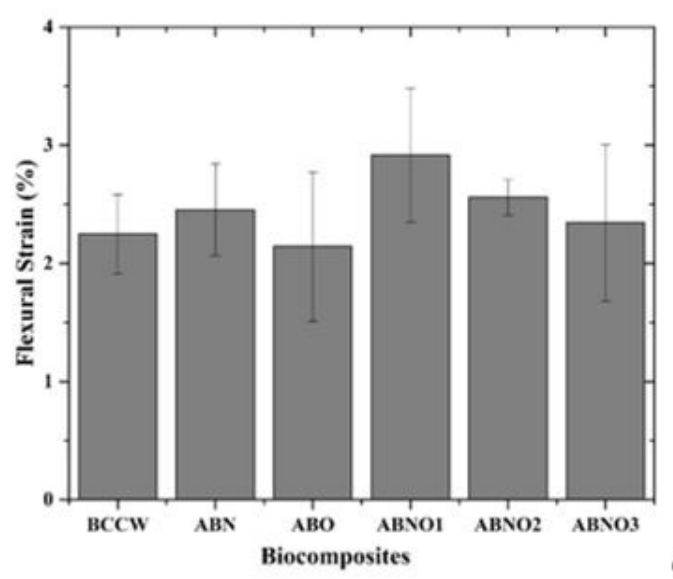

C

Figure 4. (A) Maximum flexural strength values of biocomposites. Average value \pm standard deviation is reported. Different superscripts in each column indicate significant differences $(\mathrm{p}<0.05)$; (B) Flexural modulus values of biocomposites. Average value \pm standard deviation is reported. Different superscripts in each column indicate significant differences $(p<0.05)$; (C) Flexural strain percentages of biocomposites. Average value \pm standard deviation is reported.

region of the biocomposite and depends on chain mobility. Tm is determined by crustalline region transition (Godbole et al., 2003).

Table 3 shows that the PLA $\operatorname{Tg}\left(58.17^{\circ} \mathrm{C}\right)$ decreased in $\mathrm{ABO}$, and increased in $\mathrm{ABN}, \mathrm{ABNO} 1, \mathrm{ABNO} 2$, and $\mathrm{ABNO} 3$. A reduction 
Table 3. Thermal properties of biocomposites found in DSC.

\begin{tabular}{|c|c|c|c|c|c|c|}
\hline Composite & $\operatorname{Tm}_{1}\left({ }^{\circ} \mathrm{C}\right)$ & $\operatorname{Tg}\left({ }^{\circ} \mathrm{C}\right)$ & $\operatorname{Tm}_{2}\left({ }^{\circ} \mathrm{C}\right)$ & $\Delta \mathrm{H}_{1}(\mathrm{~J} / \mathrm{g})$ & $\Delta \mathrm{H}_{2}(\mathrm{~J} / \mathrm{g})$ & $\mathrm{X}_{\mathrm{c}}$ \\
\hline Cassava bran & 139.37 & 83.5 & 162.44 & 6.016 & 221.95 & - \\
\hline PLA & 141.91 & 58.17 & - & 33.78 & & 72.64 \\
\hline $\mathrm{ABN}$ & 147.9 & 59.58 & 158.14 & 3.58 & 177.7 & 7.70 \\
\hline $\mathrm{ABO}$ & 118.06 & 48.05 & 148.91 & 0.68 & 135.25 & 1.46 \\
\hline ABNO1 & 145.42 & 71.06 & 171.57 & 2.72 & 142.3 & 5.8 \\
\hline $\mathrm{ABNO} 2$ & 118 & 71.29 & 147.3 & 1.12 & 189.5 & 2.40 \\
\hline ABNO3 & - & 71.73 & 134.93 & - & 90.75 & - \\
\hline BCCW & 146.94 & 52.16 & 166 & 8.874 & 144.8 & - \\
\hline
\end{tabular}
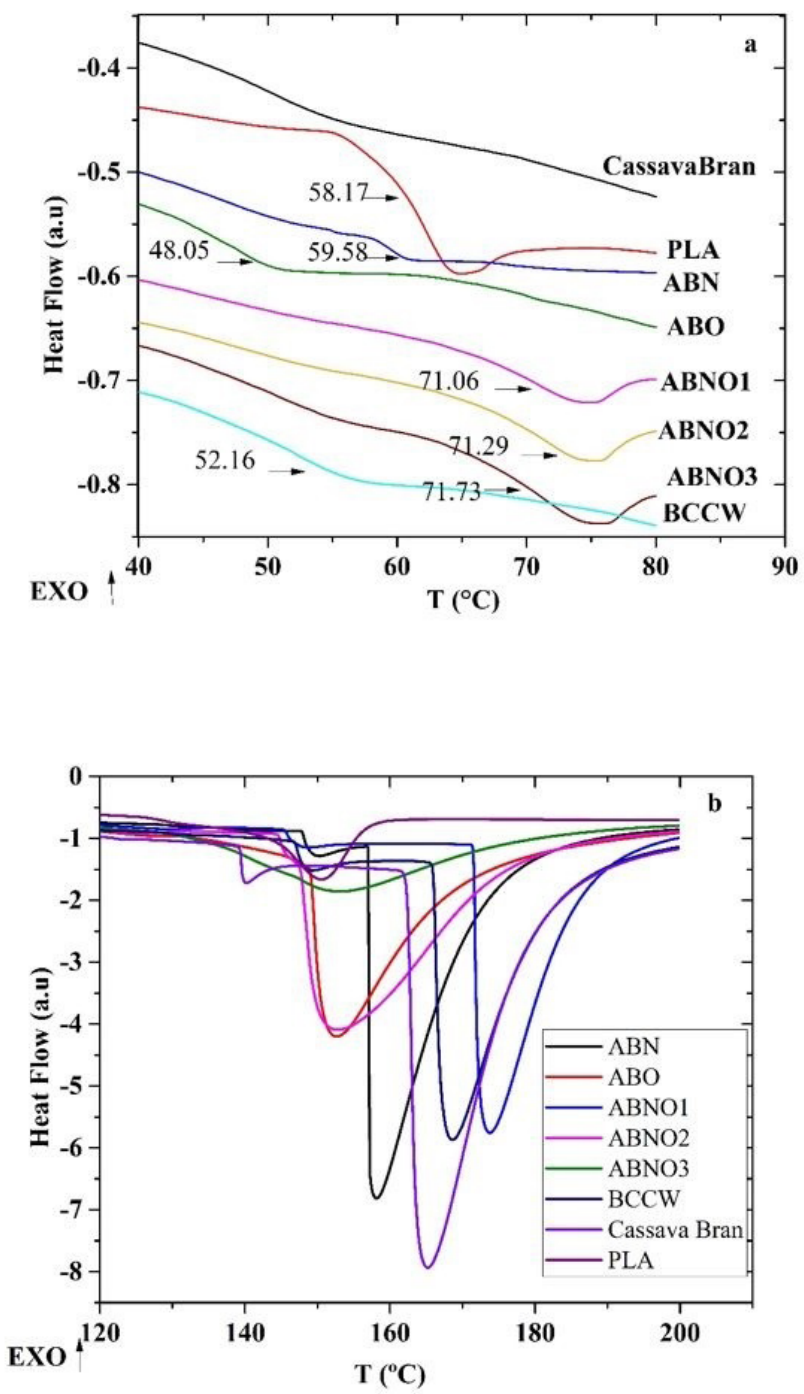

Figure 5. DSC measurement curves of $A B$, Cassava bran and PLA. (a) curves associate with the glass transition of each $\mathrm{AB}$; (b), curves associate with the melting peak of each $\mathrm{AB}$.

in Tg may indicate improved compatibility in the biocomposite, likely due to the hydrophobic character of the OVEO, which allowed for a better distribution in the PLA matrix and gave rise to a plasticizing effect. Some researchers suggest that plasticizing effects result from the presence of added hydrophobic side chains in the biocomposite (Aburto et al., 1997). The ABO phase has a lower crystallinity, possibly due to the enhanced OVEO dispersion. The Xc decreases in samples with higher oil content. When these values are near zero, they indicate that structures are more amorphous. For example, as Xc is reduced, the structure of the sample is less stiff, more flexible, and therefore easier to process than the PLA. Similar results were obtained by Anuar et al. (2017) in PLA samples with added cinnamon oil.

The addition of plasticizers, which are often low in molecular weight, increases interchain spacing (increased free volume) and reduces interactions between the polymer chains. In this way, the chains with greater mobility require lower temperatures for the change from glassy to gummy solid, resulting in the decrease of Tg values (Chaléat et al., 2014). In other the biocomposites, the addition of nisin filled the spaces in the matrix, which may explain the increase in $\mathrm{Tg}$. If the $\mathrm{Tg}$ is higher than room temperature, it implies that the mixtures are thermally stable. Godbole et al. (2003), in their study of biocomposites mixed with starch also showed an increase in $\mathrm{Tg}$. The $\mathrm{Tg}$ values of cassava bran, at a humidity of $8 \%$, and after erasing its thermal history, yielded a value of $83.5^{\circ} \mathrm{C}$, similar to the $\mathrm{Tg}$ reported in potato starch (Thiewes \& Steeneken, 1997). In the BCCW that contained water, the $\mathrm{Tg}$ decreased with respect to bran, at $52.15^{\circ} \mathrm{C}$, since the water acts as a plasticizer, causing starches to flow, and making them suitable for thermoplastic processing (Satyanarayana et al., 2009).

According to Shiroodi et al. (2016) the results of Tg, Tm, and $\Delta \mathrm{H}$, in biocomposites added to nisin, were not influenced by concentrations similar to those used in this study. Similar results have been reported by other researchers as well (Bastarrachea et al., 2010; Prapruddivongs \& Sombatsompop, 2012).

Compared to pure PLA, which shows a Tg and a melting peak, all the biocomposites, with the exception of $\mathrm{ABNO}$, showed a sharp $\mathrm{Tg}$ and two different melting peaks, a phenomenon also found with pure bran. A similar situation is also shown by (Battegazzore et al., 2014; Martin \& Avérous, 2001) in starch, fiber, and PLA biocomposites. Said studies explain this biphasic endotherm phenomenon in several ways. In the first explanation, when the volume fraction of starch increases, a multiple melting profile is observed, which implies that the granular structures respond differently in environments with low humidity. When starch is heated in the presence of excess humidity, crystallites are 
destabilized and begin melting, as a result of stresses exerted by the amorphous regions, which are fully hydrated and swollen. This gives rise to endotherm $M_{1}$. As water becomes a limiting factor, only a part of the crystallites is destabilized by this mechanism, while the rest leads to the second endotherm $\mathrm{M}_{2}$. In the second explanation, the granules with the least stable crystallites melt first $\left(M_{1}\right)$, and this results in the absorption of more water by the disordered chains. This means that the remaining crystallites and granules have less water available (the effective volume fraction of diluent is reduced) and will therefore melt at a higher temperature $\left(\mathrm{M}_{2}\right)$. Another cause has been attributed to a slow plasticization of the amorphous granular regions under restricted water conditions, which displaces the melting of the crystallites to higher temperatures (BeMiller \& Whistler, 2009).
The data in Table 3 confirms that the BCCW does not induce the crystallization of PLA during the cooling process (absence of $\mathrm{Tc}$ ). The presence of starch in the samples is responsible for the appearance of two melting peaks. A decrease in crystallinity is reflected in the decrease in the enthalpy of fusion, $\Delta \mathrm{H}$, of the biocomposites, an aspect that explains the decrease in bending stress. As seen in Table 3, the value of $\Delta \mathrm{H}_{1}$ was higher in the BCCW, which had the highest bending stress.

\subsection{Morphometry by scanning electron microscopy}

The surfaces and cross sections of the biocomposites were evaluated using scanning electron microscopy. Figure 6a shows scanning electron micrographs of the outer surface, at
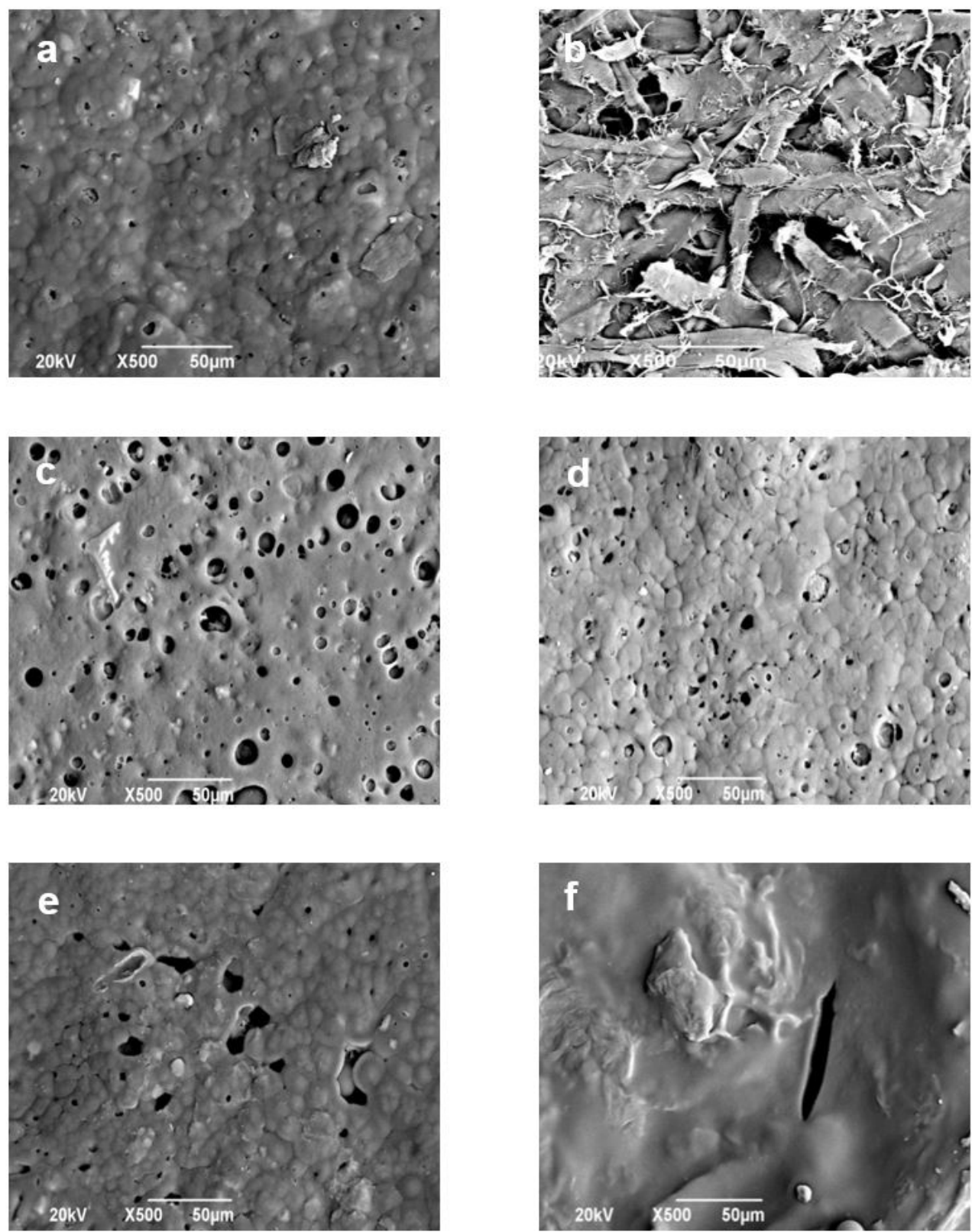

Figure 6. Scanning electron microscopy surface section. (a) ABN; (b) ABO; (c) ABNO1; (d) ABNO2 (e); ABNO3; (f) BCCW. Author's name: Karen Muñoz. 
$500 \times$ magnification. The structure of $\mathrm{ABN}$ appears compact, with a uniform polymeric network smaller than both $\mathrm{ABO}$ and BCCW. The SEM photomicrographs of the biocomposites with PLA show areas with uniform holes that could represent the deposits of nisin or OVEO in the matrix of the biocomposite. Likewise these spaces may be due to the release of the solvent into the atmosphere. In general, the images indicate a well-mixed and integrated structure, which shows a uniform distribution of the nisaplin compound in the PLA matrices. Similar results were obtained by Jin \& Zhang (2008). However, more irregular structures were observed in ABO. Figure $7 \mathrm{~b}$ shows the cross section and measurement of the PLA layer that varies between $0.576 \mathrm{~mm}$ and $0.0178 \mathrm{~mm}$.

\subsection{Antimicrobial activity in pork meat}

Based on the variance analysis, the $\mathrm{AB}$ and the evaluation carried out during storage time, there was an effect on the
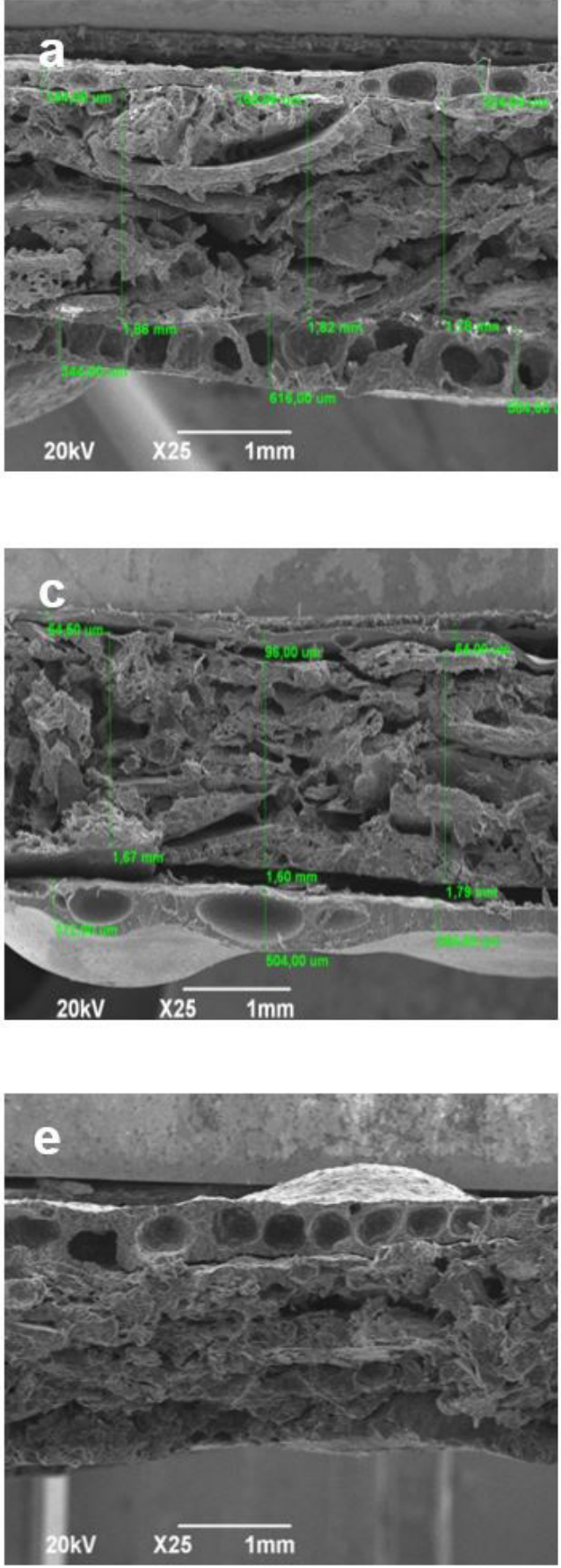
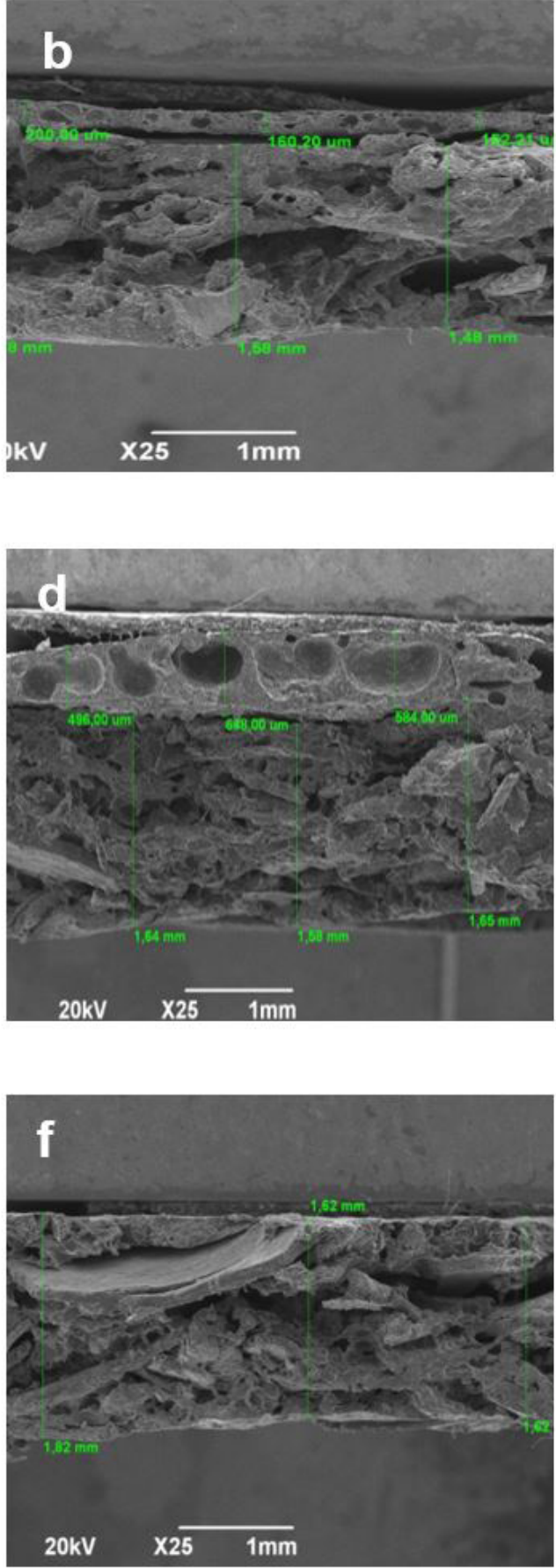

Figure 7. Scanning electron microscopy cross section. (a) ABN; (b) ABO; (c) ABNO1; (d) ABNO2; (e) ABNO3; (f) BCCW. Author's name: Karen Muñoz. 
inhibition of the three pathogenic bacteria in question $(\mathrm{P}<0.05)$. Figure 8 shows that from day zero on, all bacteria have approximately $6 \log \mathrm{CFU} / \mathrm{g}$. The Tukey's test performed on day 1 showed that S. typhimurium did not indicate a significant difference with respect to the control, unlike E. coli and L. monocytogenes that did show differences as of day 1 . On day 3 the three bacteria showed a similar, significantly lower inhibition, with greater inhibitory power on day 10 , when the growth of the bacteria decreases to approximately $4 \log$ CFU. L. monocytogenes was more affected by the activity of the $\mathrm{AB}$ than S. typhimurium. During the meat's storage period, an antimicrobial effect close to zero was not observed as expected, taking into account that in the in vitro tests the inhibition of $\mathrm{ABNO} 3$ showed almost complete inhibition for all three bacteria. In this vein, the literature on In vitro and in vivo tests with meat has concluded that a higher concentration of active compounds is required in the latter (Burt, 2004; Guo et al., 2014). A similar phenomenon was described by other studies, which have carried out in vivo studies in foods with biocomposites using oregano essential oil (Oussalah et al., 2006; Salmieri et al., 2014b). One of the main hypotheses for the greater microbial resistance to OVEO in meat is the greater availability of nutrients, which allows bacteria to repair their damage faster than in the culture medium (Requena et al., 2019). Additionally, phenolic compounds present in OVEO can react with fatty free radicals in meat as a result of autoxidation, thus generating products with a less effective reaction than the original phenolic compounds (Kim et al., 2004).

In summary, the different concentrations of OVEO added in the PLA layer had an effect on the three pathogenic bacteria in question, while the concentration of nisin only had an effect on the Gram positive bacteria. The addition of the PLA layer along with the $\mathrm{ABNO} 3$ antimicrobials generated a $17.81 \%$ reduction in the maximum bending stress with respect to BCCW, possibly due to the plasticizing effect that OVEO has, which reduces the interaction between the chains of the molecules of the polymer (Jamróz et al., 2018). According to the SEM micrographs (Figure 7), the addition of the PLA increases the thickness of the $A B$ between approximately 0.2 and $0.5 \mathrm{~mm}$ (Figure $7 \mathrm{f}$ ). This, in turn, produces agglomerations of nisaplin or OVEO in the PLA matrix, and forms a non-compact texture with spaces. This explains the loss of effort and variations in the percentages of deformation. According to DSC results, the plasticization of the PLA layer with the OVEO decreases the percentage of crystallinity (Xc), compared to a pure PLA, thus generating an increase in the amorphous phase which is associated with the permeability of the polymer (Qin et al., 2017). This phenomenon leads to an increase in the mobility of the chains and therefore the union

\section{Days of storage E. coli}

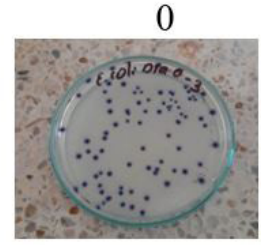

ABNO3
Commercially
L.
monocytogenes
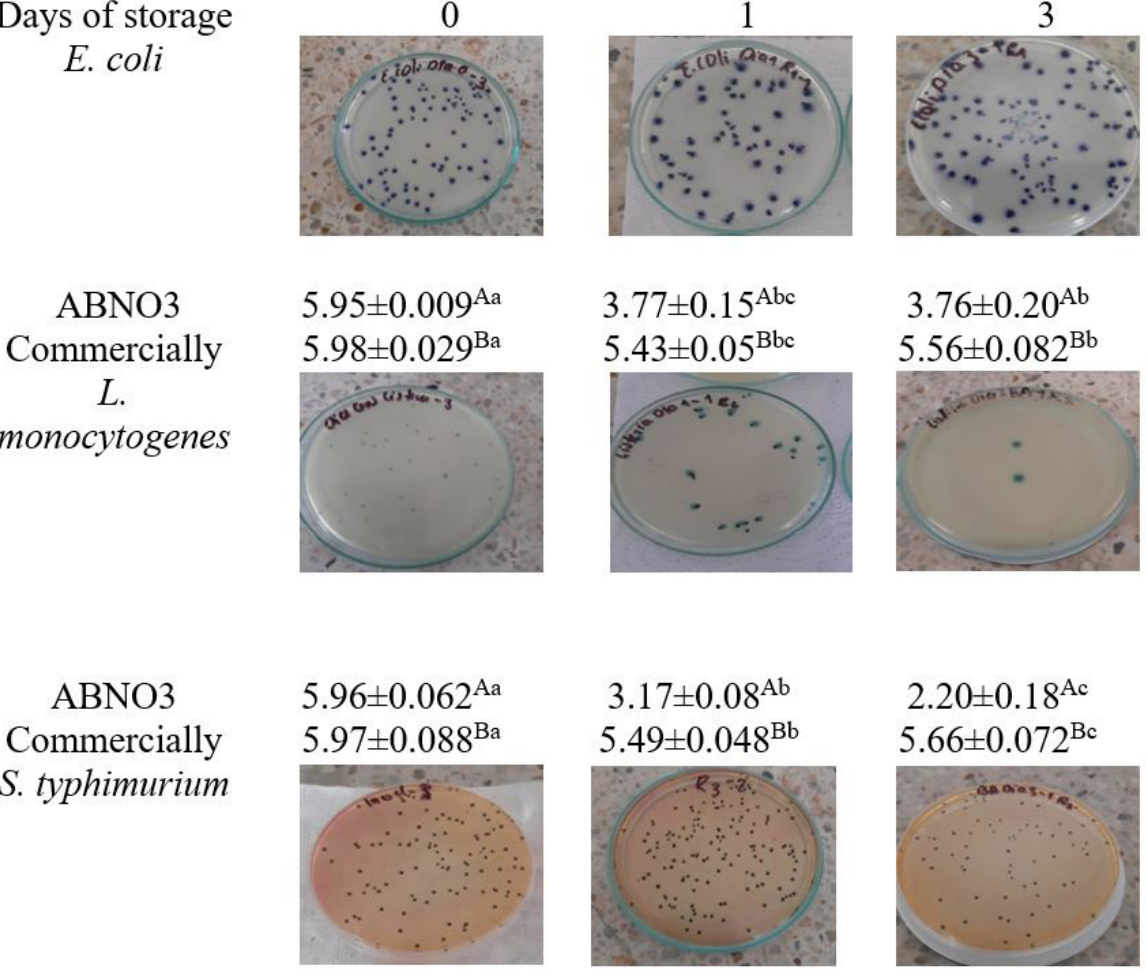

$$
\begin{array}{cc}
\text { ABNO3 } & 6.097 \pm 0.070^{\mathrm{Aa}} \\
\text { Commercially } & 5.99 \pm 0.048^{\mathrm{Ba}}
\end{array}
$$
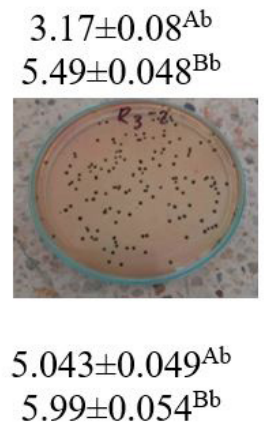

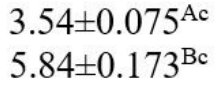

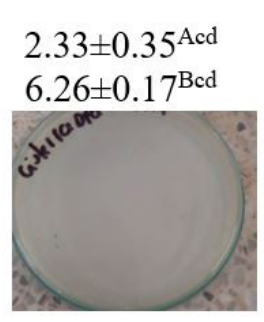
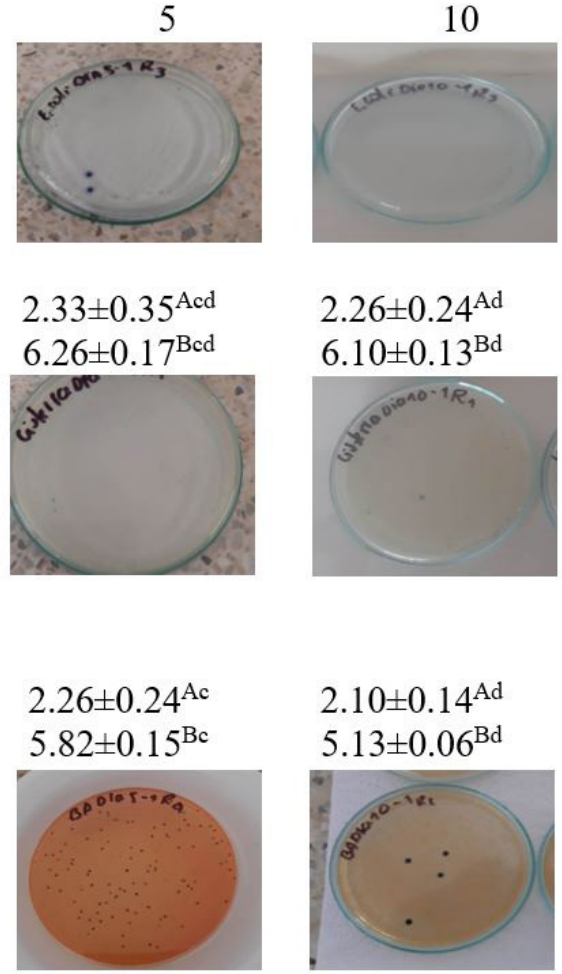

$$
\begin{gathered}
3.18 \pm 0.09^{\mathrm{Ac}} \\
5.965 \pm 0.03^{\mathrm{Bc}}
\end{gathered}
$$

Figure 8. Growth count of pathogenic bacteria over time in vivo. E. coli (CFU/g), L. monocytogens (CFU/g), S. typhimurium (CFU/g). Values are \pm standard deviation of three replicates. A, B: different letters are significantly different $(\mathrm{P}<0.05)$ between type of packaging. a, b, $\mathrm{c}$, d: the letters are significantly different $(\mathrm{P}<0.05)$ between the days of storage 
between the OVEO and the PLA, interrupting the interactions between the $A B$ and the water. Due to this process, the WVP of the ABNO3 was reduced by $90.24 \%$ with respect to BCCW, thus obtaining a polymer with low permeability.

\section{Conclusions}

The $\mathrm{AB}$, made from lignocellulosic residues (coffee husks and cassava bran), in combination with PLA, OVEO, and nisin, showed a decrease in maximum flexural strength and flexural modulus, but an increase in the percentage of deformation, water barrier, and antimicrobial properties. The addition of OVEO prevents the growth of pathogenic bacteria in vitro. The $12 \%$ concentration of the OVEO inhibited the growth of S. typhimurium, E. coli, and L. monocytogenes to nearly zero, while the effect of nisin was reflected in L. monocytogenes. FT-IR analysis allowed for characterization of the molecular interactions that occurred after the inclusion of nisin and OVEO. The $1420 \mathrm{~cm}^{-1}$ peak characteristic of phenolic compounds, such as carvacrol, increased in area as the content of oregano essential oil increased in the biocomposites. The addition of PLA-OVEOnisin increased the $\mathrm{Tg}$ for the $\mathrm{AB}$, while in the biocomposite with OVEO only, it decreased, compared to pure PLA. The percentage of crystallinity Xc decreased with OVEO content, likely due to the plasticizing effect of the latter. These data corroborated the decrease in stiffness of the biocomposites as well as an increase in deformation. OVEO interacts with PLA by altering the mobility of chains. Morphological analysis revealed a lack of adherence between PLA and starch, but positive interaction between starch and cellulose fibers in coffee husks.

This study showed the antimicrobial potential of biocomposites with added OVEO and nisin to be promising bioactive packaging for prevention of the growth of pathogenic bacteria in food products of animal origin.

\section{References}

Aburto, J., Thiebaud, S., Alric, I., Borredon, E., Bikiaris, D., Prinos, J., \& Panayiotou, C. (1997). Properties of octanoated starch and its blends with polyethylene. Carbohydrate Polymers, 34(1-2), 101-112. http://dx.doi.org/10.1016/S0144-8617(97)00053-2.

Agrawal, A. K. (2010). Spinning of poly(lactic acid) fibers. In R. Auras, L.-T. Lim, S. E. M. Selke \& H. Tsuji (Eds.), Poly(lactic acid): synthesis, structures, properties, processing, and applications. Hoboken: John Wiley \& Sons. https://doi.org/10.1002/9780470649848.ch20.

American Society for Testing and Materials - ASTM. (2008). ASTM D 3418-08: Standard Test Method for Transition Temperatures and Enthalpies of Fusion and Crystallization of Polymers by Differential Scanning Calorimetry. West Conshohocken: ASTM International. $<1$ bok>.

American Society for Testing and Materials - ASTM. (2005). ASTM E 96-05: Standard Test Methods for Water Vapor Transmission of Materials. West Conshohocken: ASTM International.

American Society for Testing and Materials - ASTM. (2010). ASTM D 790-10: Standard Test Methods for Flexural Properties of Unreinforced and Reinforced Plastics and Electrical Insulating Materials. West Conshohocken: ASTM International.

American Society for Testing and Materials - ASTM. (2013). ASTM E1252-98: Standard Practice for General Techniques for Obtaining
Infrared Spectra for Qualitative Analysis. West Conshohocken: ASTM International.

Anuar, H., Nur Fatin Izzati, A. B., Sharifah Nurul Inani, S. M., Siti Nur E'zzati, M. A., Siti Munirah Salimah, A. B., Ali, F. B., \& Manshor, M. R. (2017). Impregnation of cinnamon essential oil into plasticised polylactic acid biocomposite film for active food packaging. Journal of Packaging Technology and Research, 1(3), 149-156. http://dx.doi. org/10.1007/s41783-017-0022-1.

Bastarrachea, L., Dhawan, S., Sablani, S. S., Mah, J. H., Kang, D. H., Zhang, J., \& Tang, J. (2010). Biodegradable poly(Butylene adipateco-terephthalate) films incorporated with nisin: characterization and effectiveness against Listeria innocua. Journal of Food Science, 75(4), E215-E224. http://dx.doi.org/10.1111/j.1750-3841.2010.01591.x. PMid:20546402.

Battegazzore, D., Alongi, J., \& Frache, A. (2014). Poly(lactic acid)-based composites containing natural fillers: thermal, mechanical and barrier properties. Journal of Polymers and the Environment, 22(1), 88-98. http://dx.doi.org/10.1007/s10924-013-0616-9.

BeMiller J., \& Whistler, R. (2009). Starch: chemistry and technology (3rd ed.) London: Academic. http://www.ghbook.ir/index.php?name=sن

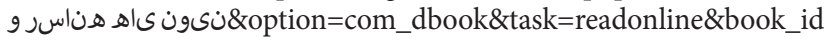
$=13650 \&$ page $=73 \&$ chkhashk=ED9C9491B4\&Itemid=218\&lang=f a\&tmpl=component

Burt, S. (2004). Essential oils: their antibacterial properties and potential applications in foods: a review. International Journal of Food Microbiology, 94(3), 223-253. http://dx.doi.org/10.1016/j. ijfoodmicro.2004.03.022. PMid:15246235.

Caetano, K. S., Hessel, C. T., Tondo, E. C., Flôres, S. H., \& Cladera-Olivera, F. (2017). Application of active cassava starch films incorporated with oregano essential oil and pumpkin residue extract on ground beef. Journal of Food Safety, 37(4), 1-9. http://dx.doi.org/10.1111/jfs.12355.

Cano, A., Jiménez, A., Cháfer, M., Gónzalez, C., \& Chiralt, A. (2014). Effect of amylose:amylopectin ratio and rice bran addition on starch films properties. Carbohydrate Polymers, 111, 543-555. http://dx.doi. org/10.1016/j.carbpol.2014.04.075. PMid:25037386.

Chaléat, C., Halley, P. J., \& Truss, R. W. (2014). Mechanical properties of starch-based plastics. In P. J. Halley \& L. Avérous (Eds.), Starch polymers: from genetic engineering to green applications (pp. 187209). Amsterdam: Elsevier. http://dx.doi.org/10.1016/B978-0-44453730-0.00023-3.

Cleveland, J., Montville, T. J., Nes, I. F., \& Chikindas, M. L. (2001). Bacteriocins: safe, natural antimicrobials for food preservation. International Journal of Food Microbiology, 71(1), 20. http://dx.doi. org/10.1016/S0168-1605(01)00560-8. PMid:11764886.

Cruz-Tirado, J. P., Barros Ferreira, R. S., Lizárraga, E., Tapia-Blácido, D. R., Silva, N. C. C., Angelats-Silva, L., \& Siche, R. (2020). Bioactive Andean sweet potato starch-based foam incorporated with oregano or thyme essential oil. Food Packaging and Shelf Life, 23, 100457. http://dx.doi.org/10.1016/j.fpsl.2019.100457.

Fael, H., \& Demirel, A. L. (2020). Nisin/polyanion layer-by-layer films exhibiting different mechanisms in antimicrobial efficacy. RSC Advances, 10(17), 10329-10337. http://dx.doi.org/10.1039/ C9RA10135G.

Gan, I., \& Chow, W. S. (2018). Antimicrobial poly(lactic acid)/cellulose bionanocomposite for food packaging application: a review. Food Packaging and Shelf Life, 17, 150-161. http://dx.doi.org/10.1016/j. fpsl.2018.06.012.

George, M., Chae, M., \& Bressler, D. C. (2016). Composite materials with bast fibres: structural, technical, and environmental properties. Progress in Materials Science, 83, 1-23. http://dx.doi.org/10.1016/j. pmatsci.2016.04.002. 
Ghanbarzadeh, B., \& Oromiehi, A. R. (2008). Biodegradable biocomposite films based on whey protein and zein: Barrier, mechanical properties and AFM analysis. International Journal of Biological Macromolecules, 43(2), 209-215. http://dx.doi.org/10.1016/j.ijbiomac.2008.05.006. PMid:18619671.

Gharsallaoui, A., Oulahal, N., Joly, C., \& Degraeve, P. (2016). Nisin as a food preservative: part 1: physicochemical properties, antimicrobial activity, and main uses. Critical Reviews in Food Science and Nutrition, 56(8), 1262-1274. http://dx.doi.org/10.1080/10408398.2013.76376 5. PMid:25675115.

Gill, A. O., \& Holley, R. A. (2006). Inhibition of membrane bound ATPases of Escherichia coli and Listeria monocytogenes by plant oil aromatics. International Journal of Food Microbiology, 111(2), 170-174. http://dx.doi.org/10.1016/j.ijfoodmicro.2006.04.046. PMid:16828188.

Godbole, S., Gote, S., Latkar, M., \& Chakrabarti, T. (2003). Preparation and characterization of biodegradable poly-3-hydroxybutyrate-starch blend films. Bioresource Technology, 86(1), 33-37. http://dx.doi. org/10.1016/S0960-8524(02)00110-4. PMid:12421006.

Godoy-Santos, F., Pitts, B., Stewart, P. S., \& Mantovani, H. C. (2019). Nisin penetration and efficacy against Staphylococcus aureus biofilms under continuous-flow conditions. Microbiology, 165(7), 761-771. http://dx.doi.org/10.1099/mic.0.000804. PMid:31088602.

Govaris, A., Solomakos, N., Pexara, A., \& Chatzopoulou, P. S. (2010). The antimicrobial effect of oregano essential oil, nisin and their combination against Salmonella enteritidis in minced sheep meat during refrigerated storage. International Journal of Food Microbiology, 137(2-3), 175-180. http://dx.doi.org/10.1016/j.ijfoodmicro.2009.12.017. PMid:20060188.

Guo, M., Jin, T. Z., \& Yang, R. (2014). antimicrobial polylactic acid packaging films against Listeria and Salmonella in culture medium and on ready-to-eat meat. Food and Bioprocess Technology, 7(11), 3293-3307. http://dx.doi.org/10.1007/s11947-014-1322-x.

Hasper, H. E., Kramer, N. E., Smith, J. L., Hillman, J. D., Zachariah, C., Kuipers, O. P., de Kruijff, B., \& Breukink, E. (2006). An alternative bactericidal mechanism of action for lantibiotic peptides that target lipid II. Science, 313(5793), 1636-1637. http://dx.doi.org/10.1126/ science.1129818. PMid:16973881.

Hossain, K. M. Z., Ahmed, I., Parsons, A. J., Scotchford, C. A., Walker, G. S., Thielemans, W., \& Rudd, C. D. (2012). Physico-chemical and mechanical properties of nanocomposites prepared using cellulose nanowhiskers and poly (lactic acid). Journal of Materials Science, 47(6), 2675-2686. http://dx.doi.org/10.1007/s10853-011-6093-4.

Huda, M. S., Drzal, L. T., Mohanty, A. K., \& Misra, M. (2008). Effect of fiber surface-treatments on the properties of laminated biocomposites from poly(lactic acid) (PLA) and kenaf fibers. Composites Science and Technology, 68(2), 424-432. http://dx.doi.org/10.1016/j. compscitech.2007.06.022.

Jamróz, E., Juszczak, L., \& Kucharek, M. (2018). Investigation of the physical properties, antioxidant and antimicrobial activity of ternary potato starch-furcellaran-gelatin films incorporated with lavender essential oil. International Journal of Biological Macromolecules, 114, 1094-1101. http://dx.doi.org/10.1016/j.ijbiomac.2018.04.014. PMid:29627470.

Jbilou, F., Galland, S., Telliez, C., Akkari, Z., Roux, R., Oulahal, N., Dole, P., Joly, C., \& Degraeve, P. (2014). Influence of some formulation and process parameters on the stability of lysozyme incorporated in corn flour- or corn starch-based extruded materials prepared by melt blending processing. Enzyme and Microbial Technology, 67, 40-46. http://dx.doi.org/10.1016/j.enzmictec.2014.08.015. PMid:25442947.
Jin, T., \& Zhang, H. (2008). Biodegradable polylactic acid polymer with nisin for use in antimicrobial food packaging. Journal of Food Science, 73(3), M127-M134. http://dx.doi.org/10.1111/j.17503841.2008.00681.x. PMid:18387115.

Jin, T., Zhang, H., \& Boyd, G. (2010a). Incorporation of preservatives in polylactic acid films for inactivating Escherichia coli O157:H7 and extending microbiological shelf life of strawberry puree. Journal of Food Protection, 73(5), 812-818. http://dx.doi.org/10.4315/0362028X-73.5.812. PMid:20501030.

Jin, T., Zhang, H., \& Boyd, G. (2010b). Incorporation of preservatives in polylactic acid films for inactivating Escherichia coli O157:H7 and extending microbiological shelf life of strawberry puree. Journal of Food Protection, 73(5), 812-818. http://dx.doi.org/10.4315/0362028X-73.5.812. PMid:20501030.

Ketkaew, S., Kasemsiri, P., Hiziroglu, S., Mongkolthanaruk, W., Wannasutta, R., Pongsa, U., \& Chindaprasirt, P. (2018). Effect of oregano essential oil content on properties of green biocomposites based on cassava starch and sugarcane bagasse for bioactive packaging. Journal of Polymers and the Environment, 26(1), 311-318. http:// dx.doi.org/10.1007/s10924-017-0957-x.

Kim, S., Ruengwilysup, C., \& Fung, D. Y. C. (2004). Antibacterial effect of water-soluble tea extracts on foodborne pathogens in laboratory medium and in a food model. Journal of Food Protection, 67(11), 2608-2612. http://dx.doi.org/10.4315/0362-028X-67.11.2608. PMid:15553649.

Kwiatkowski, P., Giedrys-Kalemba, S., Mizielińska, M., \& Bartkowiak, A. (2016). Modification of pla foil surface by ethylcellulose and essential oils. Journal of Microbiology, Biotechnology and Food Sciences, 05(05), 440-444. http://dx.doi.org/10.15414/jmbfs.2016.5.5.440-444.

Li, Q., Montalban-Lopez, M., \& Kuipers, O. P. (2018). Increasing the antimicrobial activity of nisin-based lantibiotics against gramnegative pathogens. Applied and Environmental Microbiology, 84(12), e00052-18. PMid:29625984.

Li, W., Coffin, D. R., Jin, T. Z., Latona, N., Liu, C.-K., Liu, B., Zhang, J., \& Liu, L. S. (2012a). Biodegradable composites from polyester and sugar beet pulp with antimicrobial coating for food packaging. Journal of Applied Polymer Science, 116(5), 1-12. http://dx.doi. org/10.1002/app.36885.

Li, W., Liu, L., \& Jin, T. Z. (2012b). Antimicrobial activity of allyl isothiocyanate used to coat biodegradable composite films as affected by storage and handling conditions. Journal of Food Protection, 75(12), 2234-2237. http://dx.doi.org/10.4315/0362-028X.JFP-12234. PMid:23212023.

Majid, I., Ahmad Nayik, G., Mohammad Dar, S., \& Nanda, V. (2016). Novel food packaging technologies: innovations and future prospective. Journal of the Saudi Society of Agricultural Sciences, 17(4), 454-462. http://dx.doi.org/10.1016/j.jssas.2016.11.003.

Martin, O., \& Avérous, L. (2001). Poly(lactic acid): Plasticization and properties of biodegradable multiphase systems. Polymer, 42(14), 6209-6219. http://dx.doi.org/10.1016/S0032-3861(01)00086-6.

Matsuda, D. K. M., Verceheze, A. E. S., Carvalho, G. M., Yamashita, F., \& Mali, S. (2013). Baked foams of cassava starch and organically modified nanoclays. Industrial Crops and Products, 44, 705-711. http://dx.doi.org/10.1016/j.indcrop.2012.08.032.

Molinaro, S., Cruz Romero, M., Boaro, M., Sensidoni, A., Lagazio, C., Morris, M., \& Kerry, J. (2013). Effect of nanoclay-type and PLA optical purity on the characteristics of PLA-based nanocomposite films. Journal of Food Engineering, 117(1), 113-123. http://dx.doi. org/10.1016/j.jfoodeng.2013.01.021.

Mothé, C. G., \& Miranda, I. C. (2009). Characterization of sugarcane and coconut fibers by thermal analysis and FTIR. Journal of Thermal 
Analysis and Calorimetry, 97(2), 661-665. http://dx.doi.org/10.1007/ s10973-009-0346-3.

Nakazato, G., Kobayashi, R. K. T., Seabra, A. B., \& Duran, N. (2017). Use of nanoparticles as a potential antimicrobial for food packaging. In A. M. Grumezescu (Ed.), Food preservation: nanotechnology in the agri-food industry. London: Elsevier http://dx.doi.org/10.1016/ B978-0-12-804303-5.00012-2.

Navia-Porras, D. P., Ayala-Aponte, A. A., \& Villada-Castillo, H. S. (2015). Effect of cassava flour gelatinization on mechanical properties of bioplastics. Biotecnologia en el Sector Agropecuario y Agroindustrial, 13(1), 38-44. Retrieved from https://revistas.unicauca.edu.co/index. $\mathrm{php} /$ biotecnologia/article/view/370/554

Oosterhaven, K., Poolman, B., \& Smid, E. J. (1995). S-carvone as a natural potato sprout inhibiting, fungistatic and bacteristatic compound. Industrial Crops and Products, 4(1), 23-31. http://dx.doi. org/10.1016/0926-6690(95)00007-Y.

Oussalah, M., Caillet, S., Salmiéri, S., Saucier, L., \& Lacroix, M. (2006). Antimicrobial effects of alginate-based film containing essential oils for the preservation of whole beef muscle. Journal of Food Protection, 69(10), 2364-2369. http://dx.doi.org/10.4315/0362-028X-69.10.2364. PMid:17066914.

Pamuła, E., Błazewicz, M., Paluszkiewicz, C., \& Dobrzyński, P. (2001). FTIR study of degradation products of aliphatic polyesters-carbon fibres composites. Journal of Molecular Structure, 596(1-3), 69-75. http://dx.doi.org/10.1016/S0022-2860(01)00688-3.

Pola, C. C., Medeiros, E. A. A., Pereira, O. L., Souza, V. G. L., Otoni, C. G., Camilloto, G. P., \& Soares, N. F. F. (2016). Cellulose acetate active films incorporated with oregano (Origanum vulgare) essential oil and organophilic montmorillonite clay control the growth of phytopathogenic fungi. Food Packaging and Shelf Life, 9, 69-78. http://dx.doi.org/10.1016/j.fpsl.2016.07.001.

Prapruddivongs, C., \& Sombatsompop, N. (2012). Roles and evidence of wood flour as an antibacterial promoter for triclosan-filled poly(lactic acid). Composites. Part B, Engineering, 43(7), 2730-2737. http://dx.doi.org/10.1016/j.compositesb.2012.04.032.

Qin, Y., Li, W., Liu, D., Yuan, M., \& Li, L. (2017). Development of active packaging film made from poly (lactic acid) incorporated essential oil. Progress in Organic Coatings, 103, 76-82. http://dx.doi. org/10.1016/j.porgcoat.2016.10.017.

Requena, R., Vargas, M., \& Chiralt, A. (2019). Eugenol and carvacrol migration from PHBV films and antibacterial action in different food matrices. Food Chemistry, 277, 38-45. http://dx.doi.org/10.1016/j. foodchem.2018.10.093. PMid:30502160.

Salmieri, S., Islam, F., Khan, R. A., Hossain, F. M., Ibrahim, H. M. M., Miao, C., Hamad, W. Y., \& Lacroix, M. (2014a). Antimicrobial nanocomposite films made of poly(lactic acid)-cellulose nanocrystals (PLA-CNC) in food applications: part A-effect of nisin release on the inactivation of Listeria monocytogenes in ham. Cellulose, 21(3), 1837-1850. http://dx.doi.org/10.1007/s10570-014-0230-6.

Salmieri, S., Islam, F., Khan, R. A., Hossain, F. M., Ibrahim, H. M. M., Miao, C., Hamad, W. Y., \& Lacroix, M. (2014b). Antimicrobial nanocomposite films made of poly(lactic acid)-cellulose nanocrystals (PLA-CNC) in food applications-part B: effect of oregano essential oil release on the inactivation of Listeria monocytogenes in mixed vegetables. Cellulose, 21(6), 4271-4285. http://dx.doi.org/10.1007/ s10570-014-0406-0.

Sánchez-Safont, E. L., Aldureid, A., Lagarón, J. M., Gámez-Pérez, J., \& Cabedo, L. (2018). Biocomposites of different lignocellulosic wastes for sustainable food packaging applications. Composites. Part B, Engineering, 145, 215-225. http://dx.doi.org/10.1016/j. compositesb.2018.03.037.
Santos, C. A., dos Santos, G. R., Soeiro, V. S., dos Santos, J. R., Rebelo, M. A., Chaud, M. V., Gerenutti, M., Grotto, D., Pandit, R., Rai, M., \& Jozala, A. F. (2018). Bacterial nanocellulose membranes combined with nisin: a strategy to prevent microbial growth. Cellulose, 25(11), 6681-6689. http://dx.doi.org/10.1007/s10570-018-2010-1.

Santosa, F. X. B., \& Padua, G. W. (1999). Tensile properties and water absorption of zein sheets plasticized with oleic and linoleic acids. Journal of Agricultural and Food Chemistry, 47(5), 2070-2074. http:// dx.doi.org/10.1021/jf981154p. PMid:10552498.

Satyanarayana, K. G., Arizaga, G. G. C., \& Wypych, F. (2009). Biodegradable composites based on lignocellulosic fibers: an overview. Progress in Polymer Science, 34(9), 982-1021. http://dx.doi.org/10.1016/j. progpolymsci.2008.12.002.

Schumann, B., \& Schmid, M. (2018). Packaging concepts for fresh and processed meat: recent progresses. Innovative Food Science \& Emerging Technologies, 47, 88-100. http://dx.doi.org/10.1016/j. ifset.2018.02.005

Shiroodi, S. G., Nesaei, S., Ovissipour, M., Al-Qadiri, H. M., Rasco, B., \& Sablani, S. (2016). biodegradable polymeric films incorporated with nisin: characterization and efficiency against Listeria monocytogenes. Food and Bioprocess Technology, 9(6), 958-969. http://dx.doi. org/10.1007/s11947-016-1684-3.

Silveira, V. A. I., Marim, B. M., Hipólito, A., Gonçalves, M. C., Mali, S., Kobayashi, R. K. T., \& Celligoi, M. A. P. C. (2020). Characterization and antimicrobial properties of bioactive packaging films based on polylactic acid-sophorolipid for the control of foodborne pathogens. Food Packaging and Shelf Life, 26, 1-7. http://dx.doi.org/10.1016/j. fpsl.2020.100591.

Su, J. F., Huang, Z., Zhao, Y. H., Yuan, X. Y., Wang, X. Y., \& Li, M. (2010). Moisture sorption and water vapor permeability of soy protein isolate/poly(vinyl alcohol)/glycerol blend films. Industrial Crops and Products, 31(2), 266-276. http://dx.doi.org/10.1016/j. indcrop.2009.11.010.

Syafiq, R., Sapuan, S. M., Zuhri, M. Y. M., Ilyas, R. A., Nazrin, A., Sherwani, S. F. K., \& Khalina, A. (2020). Antimicrobial activities of starch-based biopolymers and biocomposites incorporated with plant essential oils: a review. Polymers, 12(10), 1-26. http://dx.doi. org/10.3390/polym12102403. PMid:33086533.

Thiewes, H. J., \& Steeneken, P. A. M. (1997). The glass transition and the sub-Tg endotherm of amorphous and native potato starch at low moisture content. Carbohydrate Polymers, 32(2), 123-130. http:// dx.doi.org/10.1016/S0144-8617(96)00133-6.

Villada, H. S., Cajiao, E. S., \& Cerón, A. R. (2020). Material compuesto a partir de afrecho de yuca para la fabricación de recipientes y envases biodegradables. CO2018014376A1. Colombia. Retrieved from https://patents.google.com/patent/CO2018014376A1/ es? inventor $=$ cajiao\&oq $=$ cajiao

Wen, P., Zhu, D. H., Feng, K., Liu, F. J., Lou, W. Y., Li, N., Zong, M. H., \& Wu, H. (2016). Fabrication of electrospun polylactic acid nanofilm incorporating cinnamon essential oil $/ \beta$-cyclodextrin inclusion complex for antimicrobial packaging. Food Chemistry, 196, 996-1004. http://dx.doi.org/10.1016/j.foodchem.2015.10.043. PMid:26593582.

Woraprayote, W., Pumpuang, L., Tosukhowong, A., Zendo, T., Sonomoto, K., Benjakul, S., \& Visessanguan, W. (2018). Antimicrobial biodegradable food packaging impregnated with Bacteriocin 7293 for control of pathogenic bacteria in pangasius fish fillets. Lebensmittel-Wissenschaft + Technologie, 89, 427-433. http://dx.doi.org/10.1016/j.lwt.2017.10.026.

Zhang, H., Hortal, M., Dobon, A., Bermudez, J. M., \& Lara-Lledo, M. (2015a). The effect of active packaging on minimizing food losses: life cycle assessment (LCA) of essential oil component-enabled 
packaging for fresh beef. Packaging Technology and Science, 28(9), 761-774. http://dx.doi.org/10.1002/pts.2135.

Zhang, Y., Liu, X., Wang, Y., Jiang, P., \& Quek, S. Y. (2015b). Antibacterial activity and mechanism of cinnamon essential oil against Escherichia coli and Staphylococcus aureus. Food Control, 59, 282-289. http:// dx.doi.org/10.1016/j.foodcont.2015.05.032.

Zhou, X., Yang, R., Wang, B., \& Chen, K. (2019). Development and characterization of bilayer films based on pea starch/polylactic acid and use in the cherry tomatoes packaging. Carbohydrate Polymers, 222, 114912. http://dx.doi.org/10.1016/j.carbpol.2019.05.042. PMid:31320083.

Zhu, J. Y., Tang, C. H., Yin, S. W., \& Yang, X. Q. (2018). Development and characterization of novel antimicrobial bilayer films based on Polylactic acid (PLA)/Pickering emulsions. Carbohydrate Polymers, 181, 727-735. http://dx.doi.org/10.1016/j.carbpol.2017.11.085. PMid:29254029.. 